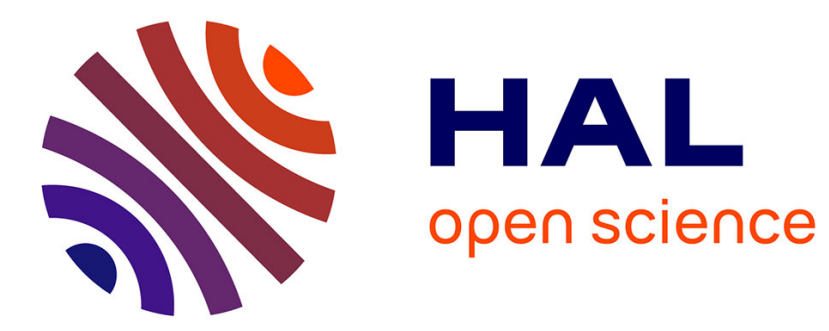

\title{
Non-Interest Income Activities and Bank Lending
}

Pejman Abedifar, Philip Molyneux, Amine Tarazi

\section{To cite this version:}

Pejman Abedifar, Philip Molyneux, Amine Tarazi. Non-Interest Income Activities and Bank Lending. 2014. hal-00947074v2

\section{HAL Id: hal-00947074 \\ https://hal.science/hal-00947074v2}

Preprint submitted on 18 Sep 2014

HAL is a multi-disciplinary open access archive for the deposit and dissemination of scientific research documents, whether they are published or not. The documents may come from teaching and research institutions in France or abroad, or from public or private research centers.
L'archive ouverte pluridisciplinaire HAL, est destinée au dépôt et à la diffusion de documents scientifiques de niveau recherche, publiés ou non, émanant des établissements d'enseignement et de recherche français ou étrangers, des laboratoires publics ou privés. 


\title{
Non-Interest Income Activities and Bank Lending
}

\author{
Pejman Abedifar*, Philip Molyneux $\dagger \mathrm{c}$, Amine Tarazi ${ }^{\S}$ \\ *School of Management, University of St Andrews, The Gateway, North Haugh, St Andrews, Fife, KY16 9RJ, UK \\ $\uparrow$ Bangor Business School, Bangor University, Wales, LL57 2DG, UK \\ $\S$ Université de Limoges, LAPE, 5 rue Félix Eboué, 87031 Limoges, France
}

August 26, 2014

\begin{abstract}
This paper investigates the impact of non-interest income businesses on bank lending. Using quarterly data on 8,287 U.S. commercial banks over 2003-2010, we find that the non-interest income activities of banks with total assets above $\$ 100$ million ('non-micro' banks) influence credit risk. In particular, banks that have higher income from fiduciary activities have lower credit risk. The impact is more pronounced during the post-crisis period. Our findings suggest that fiduciary activities induce managers to behave more prudently in lending because such activities are found to increase banks' franchise value. Other non-interest income activities that may be thought to have an influence on lending - such as service charges on deposit accounts - do not appear to have any robust relationship with the quality of credit extended. Moreover, we find little evidence of income or price crosssubsidization between traditional intermediation and non-interest income activities, except for fiduciary activities after the crisis. Furthermore, we find that micro banks suffer from diseconomies in joint production of non-interest income activities and lending.
\end{abstract}

\section{JEL Classifications: G21}

Keywords: Non-interest Income, Fiduciary, Credit Risk, Spread, Cost Complementarities

\footnotetext{
c Corresponding Author. Tel: +441248382170

E-mail addresses: pa31@st-andrews.ac.uk, p.molyneux@bangor.ac.uk, amine.tarazi@unilim.fr.

Thanks to Bob DeYoung, Iftekhar Hasan and Alain Sauviat for helpful comments on the paper. All errors, of course, rest with the authors.
} 


\section{Introduction}

A substantial empirical literature finds that bank diversification into non-interest income areas leads to banking sector instability (DeYoung and Roland, 2001; DeYoung and Rice, 2004; Stiroh, 2004; Stiroh and Rumble, 2006; Stiroh, 2006; Lepetit et al., 2008a; De Jonghe, 2010; Demirguc-Kunt and Huizinga, 2010; Moshirian et al., 2011; Brunnermeier et al., 2011; and DeYoung and Torna, 2013). The link between riskier investment banking revenue and the 2007-8 crisis has also prompted a series of reforms in the US and Europe (Dodd Frank Act, 2010; Liikanen Report, 2012 and the Independent Commission on Banking - Vickers Report, 2011) that recommend restrictions on various banks' non-interest incomebased activities (International Monetary Fund, 2011).

While the academic literature on bank diversification has focused on performance and stability issues associated with non-traditional banking activities, little attention has been paid to the potential consequences of income diversity for lending. This is somewhat surprising given that combining both traditional lending activities and non-interest businesses can affect bank/borrower relationships which form the major components of banks' charter value. It can also lead to agency problems, loss of focus and the cross-selling of fee and commission-based services as well as potential cost savings through the realization of scope economies.

Relationships with clients influence banks' performance. Banks can collect information (beyond that available publicly) over time via multiple interactions with the same customer (Berger, 1999; Boot, 2000). Boot (2000) emphasizes that relationship banking is not limited to lending and can cover other financial services. Hence, expanding the scope of client relationships may improve a bank's lending position, as it can provide opportunities to reach a wider array of potential borrowers and more information on client quality. Banks may also have the ability to monitor borrowers that are tied by non-interest activities more closely and more efficiently. Moreover, information obtained from offering multiple products can build 
new, as well as enhance, existing relationships. Such relationships can potentially increase banks' franchise value and hence increase potential indirect costs of financial distress, leading to more prudent behavior in lending and investment activities (Marcus, 1984; Keeley, 1990; Demsetz et al., 1996 and Gonzalez, 2005 show the negative relationship between banks' charter value and risk-taking).

Boot (2003) argues that scale and scope expansion leads to a form of strategic positioning that drives industry consolidation. He points out that distribution channels are essential and that technological developments that make it more effective to interrogate business-line databases encourage scope expansion.

The building of relationships can mitigate risk, as illustrated by Puri et al. (2011) who show that borrowers with prior credit relationships (with German savings banks) default less. By examining 18,000 bank loans to small Belgian firms, Degryse and Van Cayseele (2000) also show that interest rates tend to fall as the scope of the relationship expands. Hellmann et al. (2008) find that prior relationships with early stage venture capital firms increase the chances of bank loan origination. Firms may also benefit from established bank relationships by signalling their quality resulting in lower loan rates.

Incentives to cross-sell fee and non-interest based products are higher when margins on traditional intermediation are low. Carbo and Rodriguez (2007) show that income from non-traditional activities influence net interest margins through possible cross-subsidization effects and Lepetit et al. (2008b) also find that banks may charge lower rates on loans (underpricing credit risk) if they expect to obtain additional fees from borrowers. Such behavior could, therefore, undermine banks' major role in the financial system. Sound monitoring of borrowers and accurate loan-pricing are essential for the banking industry and the economy as a whole. Banks are expected to produce and convey information on the quality of borrowers 
which could be biased if non-interest activities provide incentives for weaker loan screening and monitoring.

Moreover, a greater reliance on non-interest activities may increase credit risk due to agency problems or/and a loss of focus. Several studies show that agency problems and information asymmetries stemming from activity diversification outweigh the benefits from scope economies (Laeven and Levine, 2007; Elyasiani and Wang, 2009; Akhigbe and Stevenson 2010). Others, such as Petersen and Rajan (1995) note that banks extend credit subsidies to young firms and expect to offset the expected loss through future long-run rents. In a similar vein, a diversified commercial bank may decide to grant loss-making loans to cross-sell profit-making fee and commission-based services. Banks expanding into noninterest income activities may also lose their focus on lending. Moreover, lower credit exposure may encourage managers to be less conservative in their loan-granting activities.

In this paper, we investigate the impact on lending of banks' diversification into six major business lines ${ }^{1}$ which we identify as playing an important role among a broader array of non-interest income items. They range from activities such as fiduciary where clients entrusts funds for asset management by the banks, to loan servicing which is directly attached to lending. Generally, these business lines provide banks with the opportunity to have access to more private information and can enable them to reach a wider array of potential customers. Moreover, they are also likely to expand the scope of relationships with clients beyond merely lending-deposit activities, providing more soft information, financial resources and also enhancing bank franchise values. Alternatively, they may cause agency problems, loss of focus or risk mispricing. We examine the influence of these activities on banks' lending in terms of loan quality and interest spread. We also investigate the role of bank

\footnotetext{
${ }^{1}$ Fiduciary, life insurance and annuity sales, other insurance services, loan servicing, loans sale and service charges on deposit accounts.
} 
charter/franchise value as well as the possible existence of cost complementarity or diseconomies of joint production between non-interest income activities and lending.

We use quarterly data on 8,287 U.S. commercial banks and our data span from 2003 to 2010 covering the period before and after the 2007-2008 financial crises. Since the U.S. banking system is dominated by small banks, we also study banks with less than $\$ 100$ million in total assets (3,116 'micro' commercial banks) separately from the rest of our sample.

Our credit risk analysis for commercial banks with total assets above $\$ 100$ million indicates that among our various non-interest income activities only an increase in income from fiduciary activities lowers credit risk. In other words, banks that manage clients investments (asset management) have lower credit risk. The impact is more pronounced during the post-crisis period and this finding is robust across different specifications, credit risk proxies and estimation techniques. Further investigation also shows a positive association between fiduciary income and bank's franchise value. We do not find significant evidence to support the conjecture of cross-subsidization between traditional intermediation and noninterest income activities except for fiduciary activities after the crisis with higher income shares from this activity being associated with lower lending-deposit spreads. This result is particularly important, since previous studies (Carbo and Rodriguez, 2007 and Lepetit et al., 2008b) typically find evidence of cross-subsidization effects.

Our analysis of micro commercial banks (those with assets under $\$ 100$ million) provides us with little evidence to support any significant link between non-interest income activities and credit risk, and price cross-subsidization ${ }^{2}$. Finally, we investigate for possible pair-wise cost complementarity or alternatively diseconomy of joint production between lending (both secured and unsecured) and non-interest income activities. The analysis shows that micro commercial banks suffer from diseconomy of joint production, whereas non-micro

\footnotetext{
${ }^{2}$ Non-interest income activities have too small weight in total operating income of these banks to affect their lending.
} 
commercial banks neither suffer from diseconomy of joint production nor benefit from cost complementarity (non-jointness).

The remainder of the paper is organized as follows: Section 2 outlines our methodology and econometric specifications. Section 3 describes the data and summary statistics. Section 4 discusses the results and finally section 5 concludes.

\section{Econometric Specification and Methodology}

Initially, we investigate the impact of non-interest income activities on lending from two perspectives, namely, on how it influences credit risk and interest spreads. For this purpose, we estimate the following models based on Berger and DeYoung (1997) and Carbo and Rodriguez (2007). The variables we consider are the determinants of credit risk and lending-deposit spread highlighted in the literature (McShane and Sharpe, 1985; Clair, 1992; Angbazo, 1997; Kwan and Eisenbeis, 1997; Maudos and De Guevara, 2004; Dell'Ariccia and Marquez, 2006; Ogura, 2006; Lepetit et al., 2008b; Foos, et al., 2010):

$$
\begin{aligned}
\text { Credit_Risk }_{\mathrm{i}, \mathrm{t}}= & \alpha_{0}+\alpha_{1} \times \text { Credit_Risk }_{\mathrm{i,t-1}}+\sum_{k=1}^{6} \alpha_{2, \mathrm{k}} \times \text { Non-interest_Income_Activities }_{\mathrm{k}, \mathrm{i}, \mathrm{t}}+ \\
& \alpha_{3} \times \text { Capital }_{\mathrm{i}, \mathrm{t}}+\alpha_{4} \times \text { Inefficiency }_{\mathrm{i}, \mathrm{t}}+\alpha_{5} \times \text { Risk_Weighted_Assets }_{\mathrm{i}, \mathrm{t}}+ \\
& \alpha_{6} \times \text { Loan_Commitment }_{\mathrm{i}, \mathrm{t}-1}+\alpha_{7} \times \mathrm{Loan}_{-} \text {Growth }_{\mathrm{i}, \mathrm{t}-1}+ \\
& \alpha_{8} \times \text { Size }_{\mathrm{i}, \mathrm{t}-1}+\alpha_{9} \times \log (\text { Age })_{\mathrm{i}, \mathrm{t}-1}+ \\
& \alpha_{10} \times \mathrm{HHI}_{\mathrm{j}, \mathrm{i}}+\alpha_{11} \times \text { Home_Price_Growth }_{\mathrm{j}, \mathrm{t}}+\alpha_{12} \times \text { Income_Growth }_{\mathrm{j}, \mathrm{t}-1}+ \\
& \sum_{y=1}^{7} \alpha_{13, \mathrm{y}} \times \text { Year_Dummies }_{\mathrm{k}}+\varepsilon_{\mathrm{i}, \mathrm{t}}
\end{aligned}
$$

$$
\begin{aligned}
\text { Spread }_{\mathrm{i}, \mathrm{t}}= & \beta_{0}+\beta_{1} \times \text { Spread }_{\mathrm{i}, \mathrm{t}-1}+\sum_{k=1}^{6} \beta_{2, \mathrm{k}} \times \text { Non-interest_Income_Activities } \\
& \beta_{3, \mathrm{i}, \mathrm{t}} \times \text { Capital }_{\mathrm{i}, \mathrm{t}}+\beta_{4} \times \text { Infficiency }_{\mathrm{i}, \mathrm{t}}+ \\
& \beta_{5} \times \text { Credit_Risk }_{\mathrm{i}, \mathrm{t}}+\beta_{6} \times \text { Liquidity_Risk }_{\mathrm{i}, \mathrm{t}}+\beta_{7} \times \text { Interest_Rate_Risk }_{\mathrm{i}, \mathrm{t}}+ \\
& \beta_{8} \times \text { Core_Deposit }_{\mathrm{i}, \mathrm{t}}+\beta_{9} \times \text { Loan_Commitment }_{\mathrm{i}, \mathrm{t}}+\beta_{10} \times \text { Wage }_{\mathrm{i}, \mathrm{t}}+ \\
& \left.\beta_{11} \times \text { Size }_{\mathrm{i}, \mathrm{t}}+\beta_{12} \times \text { Log(Age }\right)_{\mathrm{i}, \mathrm{t}}+ \\
& \beta_{13} \times \mathrm{HHI}_{\mathrm{j}, \mathrm{t}}+\beta_{14} \times \text { Home_Price_Growth }_{\mathrm{j}, \mathrm{t}}+\beta_{15} \times \text { Income_Growth }_{\mathrm{j}, \mathrm{t}}+ \\
& \sum_{y=1}^{7} \beta_{16, \mathrm{y}} \times \text { Year_Dummies }_{\mathrm{y}}+\eta_{\mathrm{i}, \mathrm{t}}
\end{aligned}
$$

where individual banks, time dimension and U.S. states in which they operate are represented by $\mathrm{i}, \mathrm{t}$ and $\mathrm{j}$ subscripts, respectively. Variation in credit risk (Credit Risk) and lending-borrowing spread (Spread) are modelled in Equations (1) and (2) as a function of our 
variables of interest, namely, income shares from various non-interest income activities including fiduciary activities, life insurance and annuities, other insurance services and loan servicing. These are activities that are expected to increase the scope of banking operations and extend the relationship with borrowers. Moreover, we also take into account non-interest income from loan sales and also service charges on deposit accounts. The former represents how active banks are in their loan portfolio management and the latter how actively clients do banking (the scale of relationship) and/or banks' market power. Both models also include a range of bank-level, U.S. state-level and time control variables.

We use a dynamic panel setting for our study as suggested by Carbo and Rodriguez, 2007 and Berger and DeYoung, 1997. This allows us to address the persistence in bank risktaking which is also pointed out by previous literature (Delis and Kouretas, 2011, among others). We estimate the models using the fixed effect technique, similar to Loutskiana $(2011)^{3}$.

\subsection{DEPENDENT VARIABLES}

In model (1) we use the ratio of non-performing loans to gross loans (Non-performing Loans) as a proxy for Credit Risk. Non-performing loans consist of non-accrual loans and loans which are past due for 90 days or more and still accruing. As a robustness check, we consider the ratio of loan loss reserves to gross loans (Loan Loss Reserve) and the ratio of loan loss provisions to average gross loans (Loan Loss Provision). The former represents managers' appraisal of the loan portfolio quality. It accounts for both non-performing and performing loans. The latter is a flow proxy for loan quality as it shows the quarterly

\footnotetext{
${ }^{3}$ In the dynamic panel specification, the lagged dependent variable becomes endogenous when the sample has a small time dimension (the literature considers the problem for a sample with less than 15 time periods, whereas in this study we have 32 time periods). Roodman (2009) also suggests applying difference and system GMM techniques to panels with small $\mathrm{T}$ and large $\mathrm{N}$. He points out that with large $\mathrm{T}$, a dynamic panel bias becomes insignificant and the straightforward fixed effect technique can be used. In fact, the number of instruments in difference and system GMM tends to explode with $\mathrm{T}$.
} 
adjustment of loan loss reserves and loans write-off. We also use the more generic Credit Risk proxy, namely the ratio of risk weighted assets to total assets (Risk Weighted Assets) which is considered by the Basel Accord to measure the riskiness of banks' assets and it also accounts for off balance sheet items (Cordell and King, 1995; Jones and King, 1995 and Berger and DeYoung, 1997). These proxies are widely used in the literature as accounting-based credit risk indicators (for instance Kwan and Eisenbeis, 1997; Gonzalez, 2005; Carbo and Rodriguez, 2007; Delis and Kouretas, 2011; Fiordelisi, et al., 2011).

For our Spread model (2) we use the lending-borrowing spread otherwise known as the net interest spread and defined as $\frac{\text { total interest income }}{\text { average total earning assets }}-\frac{\text { total interest expense }}{\text { average total interest-bearing liabilities }}$ (Spread) following Carbo and Rodriguez (2007) and Lepetit et al. (2008b).

\subsection{VARIABLES OF INTEREST}

On the basis of the breakdown provided in the Federal Financial Institutions Examination Council (FFIEC) 031 Reports of Income and Condition (Call Reports), we identify six major non-interest income business lines that may have an impact on customer credit relationships and banks' lending ${ }^{4}$.

1) Income from fiduciary activities (Fiduciary).

Clients using fiduciary services have entrusted assets to the bank for management or safekeeping, and hence are expected to be relatively risk-averse. Moreover, banks do not have an unconditional obligation to pay a pre-determined interest rate; instead, they simply receive a fee for the services. The trust of such clients is worthy and valuable for the banks and is likely to increases banks' franchise value. We expect that

\footnotetext{
${ }^{4}$ Due to a lack of data, we are unable to take into account income from venture capital activities. Moreover, the data on securities brokerage and investment banking is available merely as of 2007 onward. Because we focus primarily on lending we do not analyze various other items of non-interest income which are not expected to expand the scope of clients' relationships. These other items include trading revenues and other assets sales.
} 
banks with more Fiduciary Activities have less incentive for risky lending and excessive risk-taking ${ }^{5}$ because of the higher bankruptcy costs in case of failure (Marcus, 1984; Keeley, 1990).

2) Earnings on/increases in value of cash surrender value of life insurance policies plus fees and commissions from annuity sales (Life Insurance).

Clients can establish a long-run relationship and provide banks with fairly stable funding by entrusting cash surrender value on their policies to the bank. This financial resource is likely to enhance the bank's position in lending.

3) Underwriting income from insurance and reinsurance activities and income from other (non-life) insurance activities (Other Insurance Services).

Other insurance income provides banks with financial resources (pool of premiums) that may also be linked to lending. Banks that have more general insurance business are likely to be aware of the items insured - autos, residential and commercial property, other high value goods - that may require re-financing in the future and therefore can suggest lending opportunities. In addition, existing borrowers may request insurance services which might strengthen relationships and therefore enhance banks' lending quality.

4) Net servicing fees (Loan Servicing). ${ }^{6}$

Servicers can collect soft information and identify borrowers who regularly fulfil their repayment obligations and this information can be used by banks for future loan origination. However, to collect more late fees, servicing companies may target borrowers less likely to make timely instalments (Wagner, 2009). Moreover, having

\footnotetext{
${ }^{5}$ It can be argued that clients have a strong preference for using reputable and conservative banks for their fiduciary activities. We address this causal relationship in sub-sections 4.5 and 4.6.

${ }^{6}$ Servicing companies typically receive a percentage of the outstanding amount of the loans they service. Normally, they do not own the loans. Services include statements, impounds, collections, tax reporting, and other requirements. Any person with a mortgage loan pays her scheduled instalments to a loan servicing firm. Most of mortgages are backed by Federal housing programs such as Fannie Mae and Freddie Mac.
} 
loan servicers, banks may undermine loan quality and originate more mortgage loans while under-pricing risk. As such, the relationship between Loan Servicing and lending quality is indeterminate prior to estimation.

5) Net gains (losses) on sales of loans and leases and net securitization income (Loan Sales).

Income from Loans Sale may show how active banks manage their loan portfolio; however, banks with more effective presence in the loan sales market may target riskier loans. As such, the relationship between Loans Sale and loan quality is not clear.

6) Service charges on deposit accounts in domestic offices, income and fees from the printing and sale of checks, income and fees from automated teller machines and bank card and credit card interchange fees (Service Charge).

Service Charge represents the scale of relationships as it can show the volume of interactions with clients and how much income can be obtained from such activities (banks' market power). Hence, we expect that banks with more income from these services might have a greater charter value. Alternatively, a higher service charge might be due to a bank's pricing policy or even the quality of clients - riskier clients will likely pay higher service fees, suggesting a reverse relationship with franchise value.

Our aim is to analyse the implications for credit risk and spread resulting from variation in the aforementioned non-interest income activities. The income from such activities is measured as a percentage of total net operating income following the existing literature (Stiroh, 2004 among others). For Equation (2), however, we scale the non-interest income items by total assets in lieu of total net operating income, since the latter includes net 
interest income (alongside non-interest income) and this may cause a mechanical inverse relationship between the share of non-interest income in total operating income and Spread ${ }^{7}$.

\subsection{CONTROL VARIABLES}

The ratio of equity capital to total assets (Capital) is controlled for in both models. On the one hand, higher Capital is associated with lower moral hazard problems and better capitalized banks have greater monitoring incentives (Diamond, 1984). On the other hand, equity capital provides banks with an enhanced capacity for risk-taking. It can represent equity-holders' risk preferences (McShane and Sharpe, 1985 and Maudos and De Guevara, 2004) and banks with a higher capital ratio may target riskier activities and/or a higher spread to compensate for the higher cost of equity compared to debt finance. Berger (1995) argues that capital requirements translate into a premium on margins. We also control for cost inefficiency represented by the ratio of non-interest expense to total operating revenue (Inefficiency) in our models. Less efficient banks are expected to have lower loan quality due to poorer monitoring. They might even have greater incentives for risk-taking (Kwan and Eisenbeis, 1997). More inefficient banks are expected to increase their spread to cover their higher costs (Altunbas et al., 2001).

We include the ratio of the face value of unused credit lines and loan commitments to total assets (Loan Commitment) in our analysis. Borrowers of banks with higher Loan Commitment face, on average, lower liquidity shocks and have the capacity to be more leveraged. As such, we expect a negative relationship between Loan Commitment and Credit Risk. Berg et al. (2013) show that credit lines act as insurance for borrowers against liquidity shocks and the related fees including commitment fees smooth borrowing costs across

\footnotetext{
${ }^{7}$ An increase in non-interest income share might be due to a decline in net interest income caused by a decrease in Spread.
} 
different scenarios (namely, the presence and absence of liquidity shocks). As such, higher Loan Commitment may represent greater borrowing cost smoothing and lower Spread.

In our Credit Risk model (1) we control for Risk Weighted Assets, as non-performing loans depend on the riskiness of portfolio structure and Risk Weighted Assets captures a number of risk factors such as borrowers' type and the existence of collateral (Berger and DeYoung, 1997).

We add the quarterly growth rate of gross loans (Loan Growth) to the Credit Risk model, since the literature shows a negative relationship between credit expansion and loan quality (Clair, 1992; Dell’Ariccia and Marquez, 2006; Ogura, 2006; Foos, et al., 2010).

In the Spread model (model 2), we introduce a proxy for credit risk (Loan Loss Provision), the ratio of liquid assets to total liabilities (to capture liquidity risk) and the difference between the annualized federal funds rate and the implicit interest rate on customer deposits as a measure of interest rate risk. We expect higher credit, liquidity or interest rate risk to translate into higher Spread (Angbazo, 1997; Carbo and Rodriguez, 2007 and Saunders and Schumacher, 2000 among others). The share of core deposits in total liabilities (Core Deposit) is also included in Equation (2), as Spread depends on the structure of debt financing. We also consider the salaries and employee benefits divided by number of full time equivalent employees (Wage) as a proxy for employees' expertise. Banks with greater expertise are expected to have a higher Spread, since they are expected to offer more specialized and higher valued services.

We also control for bank size by including the logarithm of total assets (Size) in both models. Size can have several impacts on Credit Risk and Spread: Large and small banks have different business models, the former relying more heavily on non-interest generating activities given their greater capacity to benefit from diversification and scale economies (Hughes et al., 2001). Larger banks may also hold riskier loan portfolios to benefit from safety 
net subsidies (Kane, 2010). Moreover, bigger banks mainly deal with larger and more transparent borrowers, while small banks are more likely to lend to opaque firms which may be more risky. Alternatively, large borrowers generally have easier access to financial markets as a substitute for bank lending. Hence, large banks could face higher competition, resulting in greater risk-taking and lower spreads. The logarithm of the bank's age $(\log (\operatorname{Age}))$ is expected to capture the impact of longevity and hence experience on the bank's Credit Risk and Spread.

In both models, we attempt to capture state-level heterogeneity by including indexes for banking market concentration (HHI), house prices (House Price Growth) and growth in personal income (Income Growth). Finally, yearly fixed effects are controlled for by introducing seven year dummies. Table A1 in the appendix outlines the variables used in our models.

\section{Data and Descriptive Statistics}

Our empirical investigation is based on a sample of 8,287 commercial banks domiciled in the U.S. The sample is constructed on a quarterly basis between 2003 and $2010^{8}$, providing a total of 211,161 bank-quarter observations. Bank-level data is collected from the web-site of the Federal Reserve Bank of Chicago, the annualized federal funds rate is obtained from the Federal Reserve Bank of New York, state-level home price indexes and personal income data are retrieved from the Office of Federal Housing Enterprise Oversight and the Bureau of Economic Analysis, respectively. The data on market capitalization is collected from the SNL database. We exclude banks that have been in operation for less than 3 years and banks with no loans and deposits. Outliers are removed from the sample by winsorizing up to $2 \%$ of each

\footnotetext{
${ }^{8}$ The time frame starts from 2003, since U.S. banks provide detailed information on various non-interest income activities since then. The Federal Reserve Bank of Chicago has not posted the CALL report data on its web-site from 2011 onward.
} 
tail $^{9}$. All the variables are de-seasonalized ${ }^{10}$ and income statement figures have been annualized. We also remove banks with negative non-interest income ratios ${ }^{11}$. We also study two samples of banks: 3,116 very small banks $(80,277$ observations) with less than $\$ 100$ million in total assets (Micro Commercial Banks). The second sample consists of the remaining 5,171 commercial banks (Non-Micro Commercial Banks) with 130,884 observations. The reason for examining the smallest banks separately is that the U.S. banking system is dominated by small banks with a relatively different business model. As banks become larger their funding strategy, loan composition and income structure tend to change.

Table I (PANEL A) presents the descriptive statistics for Micro and Non-Micro Commercial Banks. The mean equality tests show a significant difference between the two groups of banks. The figures show that Non-performing Loans of Non-Micro Commercial Banks equals $1.12 \%$ which is significantly higher than that of Micro Commercial Banks (0.92\%); nevertheless, Non-Micro Commercial Banks hold on average less Loan Loss Reserve (1.44\% vs. $1.55 \%)$ than Micro Commercial Banks. Our flow proxy of Credit Risk, Loan Loss Provision, is also higher for Non-Micro Commercial Banks (0.56\% vs. 0.35\%).

Non-Micro Commercial Banks have on average more Risk Weighted Assets (71.73\%) but lower Spread (3.54\%) than Micro Commercial Banks (with 65.32\% Risk Weighted Assets and $3.67 \%$ Spread). Non-Micro Commercial Banks are on average less capitalized and more efficient than Micro Commercial Banks. Non-Micro Commercial Banks are also less reliant on core deposits. Moreover, Non-Micro Commercial Banks hold on average less liquid assets and also pay more interest to deposit holders than Micro Commercial Banks.

\footnotetext{
${ }^{9}$ We winsorize the data to the extent that the sample lies in the (mean $-6 \times$ S.D., mean $+6 \times$ S.D.) domain. Hence, each variable is winsorized based on how dispersed its distribution is and how flat the tails are.

${ }^{10}$ We regress bank level data and the interest rate on three quarter dummies and use the residual as the deseasonalized value. The state-level data (Home Price Growth and Personal Income Growth) have already been de-seasonalized.

11 Totally, 195 observations on non-interest income scaled by total operating income are excluded from our sample. We also scale the non-interest income components by total assets, as a robustness check, in which case we do not need to exclude these observations.
} 
Loan Commitment is on average higher for Non-Micro Commercial Banks. Their gross loans grow at a faster rate and they pay on average a higher salary to their employees as compared to Micro Commercial Banks. The average age of Non-Micro Commercial Banks is about 66 years, which is approximately 10 years lower than the average age of Micro Commercial Banks. The average state-level assets market share of Micro and Non-Micro Commercial Banks are $0.08 \%$ and $0.7 \%$, respectively. The share of non-interest income activities in total operating income of Non-Micro Commercial Banks is $17.53 \%$, whereas the share is $14.08 \%$ for Micro Commercial Banks which rely significantly more on interest income $^{12}$.

\section{[TABLE I]}

The second part of the table illustrates the income shares of our variables of interest in total operating income, i.e. Fiduciary, Life Insurance, Other Insurance Services, Loan Servicing, Loan Sale and Service Charge. The descriptive statistics show that the income share for Fiduciary is $0.90 \%$ for Non-Micro Commercial Banks, while it is merely $0.06 \%$ for Micro Commercial Banks. Life Insurance, Loan Servicing and Loan Sale have a greater income share in total operating income of Non-Micro Commercial Banks, whereas the income share of Other Insurance Services and Service Charge is higher for Micro Commercial Banks.

The third part of the table exhibits other components of non-interest income. Income share of Securities Brokerage, Investment Banking and Trading have greater share in total operating income of Non-Micro Commercial banks; whereas Other Assets Sale has, on average, a negative weight in total operating income of Non-Micro Commercial Banks and almost zero weight for Micro Commercial Banks. Other non-interest income activities account for $4.45 \%$ and $3.11 \%$ of total operating income of Non-Micro and Micro Commercial banks,

\footnotetext{
${ }^{12}$ Stiroh (2006) quotes 23.9\% as the Noninterest_Income of traded BHCs operating between 1997 and 2004. Elyasiani and Wang (2009) report 24\% as the Noninterest_Income of listed BHCs operating between 2001-2005 period. The average bank considered in their studies is larger and hence more diversified than the average bank studied in our paper.
} 
respectively. The last part of the table illustrates our proxies for bank franchise value. The Market to Book Value of Non-Micro Commercial Banks is on average 127\%, whereas the market capitalization of Micro Commercial Banks is on average slightly lower than the book value of their equity capital. Tobin's $Q$ of Non-Micro Commercial Banks stands marginally above $100 \%(102.9 \%)$ and it almost equals $100 \%$ for Micro Commercial Banks.

PANEL B of the table presents the state-level indicators including the market concentration index represented by HHI, Home Price Index Growth and Income Growth. The home price index, on average, has experienced a $0.55 \%$ quarterly growth during the study period. Personal income has also grown, on average, at the rate of $1.06 \%$ in the $2003-2010$ time period.

\section{Empirical Results}

\subsection{CREDIT RISK}

We estimate the Credit Risk model (Equation (1)) using our quarterly panel data to investigate whether non-interest income activities have any significant impact on banks' loan quality. We apply the fixed effect technique with standard errors clustered at the bank level. Table II presents the estimation results for the 5,106 Non-Micro Commercial Banks and the 2,792 Micro Commercial Banks during the period under study.

Columns (1) to (7) display the results for Non-Micro Commercial Banks. Column (1) illustrates the estimation where we regress Non-performing Loans as the Credit Risk proxy on non-interest income activities, namely Fiduciary, Life Insurance, Other Insurance Services, Loan Servicing, Loan Sale and Service Charge while controlling for Capital, Inefficiency, Risk Weighted Assets and year fixed effects. In column (2), we try to capture heterogeneities caused by loan portfolio characteristics by adding Loan Commitment and Loan Growth to our model. We introduce Size and $\log ($ Age) to the model in column (3). Finally, state-level 
variations represented by HHI, Home Price Growth and Income Growth are controlled for in the fourth column. In all specifications the results show significant and negative coefficients for Fiduciary, Other Insurance Services and Service Charge implying that income from these businesses appears to lower Credit Risk. As a robustness check, in columns (5) and (6) we use Loan Loss Reserve and Loan Loss Provision as proxies for Credit Risk in lieu of Nonperforming Loan. The results support our finding for Fiduciary Activities; however, the coefficients of Other Insurance Services and Service Charge appear insignificant in column (6) where we use Loan Loss Provision. Moreover, we scale the non-interest income items by total assets in lieu of total net operating income and re-estimate our model. The results are in line with our previous findings: Fiduciary negatively affects Credit Risk. Column (7) displays the result when we use a more generic proxy for Credit Risk, i.e. Risk Weighted Assets which depicts a negative association with Fiduciary and Service Charge. As a further robustness check and following Thompson $(2011)^{13}$, the standard errors are clustered by quarter. The results support our previous findings ${ }^{14}$.

Overall, the outcome implies that income from Fiduciary Activities appears to lower Credit Risk. The result is also economically meaningful. A one percent increase, evaluated at the mean, in the income share of Fiduciary in total net operating income lowers Nonperforming Loans on average, by $0.010 \%$. The average Non-performing Loans is $1.12 \%$, so the effects are economically significant and equal to a $0.9 \%\left(0.9 \%=\frac{0.010 \%}{1.12 \%}\right)$ fall in the average Non-performing Loans.

Among the control variables, we find that more capitalized or inefficient banks have, on average, greater Credit Risk. We also observe a positive effect of Risk Weighted Assets on

\footnotetext{
${ }^{13}$ Petersen (2009) and Thompson (2011) both claim that when the dimensions of panel are extremely unbalanced, there is no need to double cluster at all; however, the former believes that single-clustering on the more frequent dimension (bank in our case) is almost identical to clustering by both dimensions, whereas the latter argues that in this case, single-clustering on the less frequent dimension (time in our case) removes the bias.

${ }^{14}$ The results are not reported here, but are available from the authors upon request.
} 
Credit Risk. Loan Commitment and Loan Growth are associated with lower Credit Risk, (except for Risk Weighted Assets for which we find positive coefficients in-line with expectations). Larger or older banks have higher Credit Risk whereas younger or older banks have greater Risk Weighted Assets. We find that an increase in Home Price Growth or Income Growth appears to lower Credit Risk. Finally, column (8) reports the estimation of our model for Micro Commercial Banks where we find no significant relationship between any of our non-interest income activities and credit risk.

[TABLE II]

\subsection{SPREAD}

In this sub-section, we investigate the relationship between non-interest income activities (Fiduciary Activities, Life Insurance, Other Insurance Services, Loan Servicing, Loan Sale and Service Charge $)^{15}$ and Spread. We use the fixed effect technique with standard errors clustered at the bank level. Table III presents the estimation results of the Equation (2) using quarterly data of 5,106 Non-Micro Commercial Banks and 2,788 Micro Commercial Banks.

Columns (1) to (5) illustrate the regression results for Non-Micro Commercial Banks. In the first column, we regress Spread on non-interest income activities, while controlling for Capital, Inefficiency and year dummies. The result shows a positive association of Fiduciary, Life Insurance and Other Insurance Services, Loan Sale and Service Charge with Spread; however, the coefficient of Fiduciary appears insignificant in the second column where we control for Loan Loss Provision, Liquid Asset and Interest Rate Risk. In column (3), we introduce Core Deposit, Loan Commitment and Wage in our model. In this specification, Other Insurance Services appears insignificant. Size and banks' age are added to the model in

\footnotetext{
${ }^{15}$ Scaled by total assets in lieu of total operating income to avoid the negative mechanical relationship with Spread.
} 
the fourth column. Column (5) displays the estimation result when we include HHI, Home Price Growth and Income Growth. In all five specifications, the results show a positive association of Life Insurance, Loan Sale and Service Charge with Spread. We study our Micro Commercial Banks sub-sample in column (6) and find a positive relationship of Fiduciary (at the ten percent significance level) and Service Charge with Spread.

The results also show that more capitalized or efficient banks have a higher Spread. A higher Loan Loss Provision translates into a higher Spread. Banks with more Liquid Asset (i.e. lower liquidity risk) have a lower Spread. Core Deposit depicts a positive association with Spread. We find a positive relationship between Loan Commitment and Spread which is contrary to our expectation. A higher Wage is associated with a higher Spread. Larger banks have, on average, lower Spread, whereas older banks have, on average, a higher Spread. Spread is higher in states with a faster Home Price Growth. Finally, we observe a negative relationship between Income Growth and Spread.

Overall, we find no evidence to support the cross-subsidization conjecture, but also we find that an increase in Life Insurance, Loan Sale or Service Charge is associated with an increase in Spread.

\section{[TABLE III]}

\subsection{CRISIS AND POST CRISIS PERIODS}

We find a robust relationship between fiduciary activities and banks' credit risk. As a further analysis, in this sub-section, we explore the relationship between Fiduciary and our dependent variables, namely Credit Risk proxies and Spread, during the crisis and afterwards. Using the definition provided by the Bank for International Settlements (2010), we split our sample period to three sub-samples: pre-crisis (January 2003 to June 2007), acute-crisis (July 2007 to March 2009) and post-crisis periods (April 2009 to December 2010). Table IV 
presents the results of our analysis for the three sub-periods, using quarterly data of 4,371 Non-Micro Commercial Banks.

Column (1) illustrates the estimation of the Credit Risk Model (Equation (1)), using Non-performing Loans as the dependent variable. We use three dummy variables of Pre, Acute and Post ${ }^{16}$ and replace Fiduciary with its interaction terms with the three dummies. We also replace our year fixed effects with Acute and Post dummy variables. The result shows that the impact of Fiduciary on Non-performing Loans is slightly stronger during the postcrisis period. In the second column, we use Loan Loss Reserve in lieu of Non-performing Loans and find almost the same impact across acute and post crisis periods. In column (3), we use Loan Loss Provision as another proxy for Credit Risk and also find that the impact of Fiduciary on Credit Risk is more pronounced during the post-crisis period. Column (4) displays our analysis when Risk Weighted Assets is used as the dependent variable. Similar to our previous findings, we find a stronger effect of Fiduciary during the post-crisis period. Finally, in the fifth column we estimate our Spread model (Equation (2)), where we replace Fiduciary with its three interaction terms with Pre, Acute and Post. The analysis shows that during the post-crisis period banks with more Fiduciary income have on average a lower Spread.

\section{[TABLE IV]}

\subsection{FIDUCIARY ACTIVITIES AND CREDIT RISK - CAUSALITY TESTS}

We find that fiduciary activities can lower credit risk; however, it might be argued that clients have a strong preference for using reputable and conservative banks for their fiduciary activities. In this sub-section, we address this causal relationship, using the Granger causality test (1969) which is widely applied in the literature (Berger, 1995; Rossi, et al., 2009;

\footnotetext{
${ }^{16}$ Pre takes the value of one for the period before the third quarter of 2007 and zero otherwise. Acute takes the value one for the period between the third quarter of 2007 and the first quarter of 2009 and zero otherwise. Post takes the value of one for the period after the first quarter of 2009 and zero otherwise.
} 
Fiordelisi et al. 2011, among others). We adopt the Berger and DeYoung (1997) model to set up the following equations to study the inter-temporal relationships between Fiduciary and Credit Risk:

Credit_Risk $_{\mathrm{i}, \mathrm{t}}=\mathrm{f}\left(\right.$ Credit_Risk $_{\mathrm{i}, \text { lag }}$, Fiduciary $_{\mathrm{i}, \mathrm{lag}}$, Capital $_{\mathrm{i}, \text { lag }}$, Inefficiency $_{\mathrm{i}, \text { lag }}$, Risk_Weighted_Assets ${ }_{\mathrm{i}, \text { lag }}, \mathrm{HHI}_{\mathrm{j}, \mathrm{t}}$, Home_Price_Growth $\mathrm{j}_{\mathrm{j}, \mathrm{t}}$, Income_Growth $_{\mathrm{j}, \mathrm{t}}, \sum_{y=1}^{6}$ Year_Dummies $\left._{\mathrm{k}}\right)+\varepsilon_{\mathrm{i}, \mathrm{t}}$

Fiduciary $_{\mathrm{i}, \mathrm{t}} \quad=\mathrm{g}\left(\right.$ Credit_Risk $_{\mathrm{i}, \text { lag }}$, Fiduciary $_{\mathrm{i}, \text { lag }}$, Capital $_{\mathrm{i}, \text { lag }}$, Inefficiency $_{\mathrm{i}, \text { lag }}$, Risk_Weighted_Assets $_{\mathrm{i}, \text { lag }}, \mathrm{HHI}_{\mathrm{j}, \mathrm{t}}$, Home_Price_Growth $\mathrm{j}_{\mathrm{j}, \mathrm{t}}$, Income_Growth $_{\mathrm{j}, \mathrm{t}}, \sum_{y=1}^{6}$ Year_Dummies $\left._{\mathrm{k}}\right)+\zeta_{\mathrm{i}, \mathrm{t}}$

Where the individual banks, time dimension and states are represented by $i, t$ and $j$ subscripts, respectively. On the right-hand-side of Equations (3) and (4), we use the lagged value of Credit Risk, Fiduciary, Capital, Inefficiency and Risk Weighted Assets while controlling for state-level variables and year dummies. Table $\mathrm{V}$ presents the estimation of our equations using the fixed effect technique. In the first column, we define three lags for the right-handside variables and estimate Equation (3). The three lags of Fiduciary appear with negative coefficients and we reject the null hypothesis that the summation of all three lags equals to zero. This shows the long-run negative causation of Fiduciary on Credit Risk. In column (2), we consider four lags for the right-hand-side variables and find similar results. The results also show that Capital negatively, but Inefficiency positively, Granger cause Credit Risk. In column (2), we also observe that in the long-run more Risk Weighted Assets translates into greater Credit Risk.

Columns (3) and (4) illustrate our estimations of Equation (4) using three and four lags, respectively. We find that Credit Risk positively Granger causes Fiduciary. Hence, we do not find any evidence suggesting that banks successful in lending attract more fiduciary services. We also observe the long-run negative causation of Capital and Inefficiency on Fiduciary, whereas an increase in the Risk Weighted Assets does not temporally precede any significant change in Fiduciary. 


\section{[TABLE V]}

\subsection{FRANCHISE VALUE}

We find that fiduciary activities lower banks' credit risk. One plausible channel for explaining this finding is a bank's franchise value. In commercial banking, the relationship with clients forms a core part of intangible assets known as franchise or charter value. Banks' clients can be classified into two main groups: 'core' deposit holders / loan takers and clients of fee-based services such as fiduciary. The relationship with these clients is valuable for banks since they provide stable financial resources and income as well as soft information.

In this section, we explore the relationship between non-interest income activities and franchise value. We adopt the following model for our analysis based on De Jonghe and Vennet (2008):

$$
\begin{aligned}
\text { Franchise_Value }_{\mathrm{i}, \mathrm{t}}=\mathrm{f}( & \sum_{k=1}^{6} \alpha_{\mathrm{k}} \times \text { Non-interest_Income_Activities }_{\mathrm{k}, \mathrm{i}, \mathrm{t}}, \text { Core_Deposit }_{\mathrm{i}, \mathrm{t}}, \\
& \text { Credit_Risk }_{\mathrm{i}, \mathrm{t}} \text { Inefficiency }{ }_{\mathrm{i}, \mathrm{t}}, \text { Capital }_{\mathrm{i}, \mathrm{t}}, \text { Market_Share }_{\mathrm{i}, \mathrm{t}}, \\
& \text { HHI } \left._{\mathrm{j}, \mathrm{t}}, \text { Home_Price_Growth }_{\mathrm{j}, \mathrm{t}} \text { Income_Growth }_{\mathrm{j}, \mathrm{t}}\right)+\varepsilon_{\mathrm{i}, \mathrm{t}}
\end{aligned}
$$

Where individual banks, time dimension and states are represented by $\mathrm{i}, \mathrm{t}$ and $\mathrm{j}$ subscripts, respectively. We use the market to book value of equity capital (Market to Book Value) as the primary proxy for bank franchise value and Tobin's $\mathrm{Q}$ (Tobin's $Q$ ) as an alternative indicator (Keeley, 1990 and Gonzalez, 2005). Tobin's $Q$ is defined as the market value of equity capital plus the book value of total liabilities divided by the book value of total assets. Variations in franchise value (Franchise Value) are modelled in Equation (5) as a function of our variables of interest, namely income shares from non-interest income activities, and a set of bank and state-level controls. At the bank level, we control for Core Deposit, Credit Risk, Inefficiency, Capital and Market Share. Core deposits are a stable source of funding representing clients' relationships and these are expected to increase bank charter value. Banks with higher credit risk and inefficiency are expected to have lower franchise values. 
We also control for capital strength using the equity capital to assets ratio as banks with less capital are likely to be more risky and hence have lower franchise value. Market share is expected to be positively linked to charter value (Opler and Titman, 1994). We also include HHI, Home Price Growth and Income Growth to control for state-level heterogeneity.

We estimate the Franchise Value model (Equation (5)) using 1,882 quarterly panel data of 187 listed Non-Micro Commercial Banks and the fixed effects technique. Since the dimensions of our panel data are not extremely unbalanced, following Petersen (2009) and Thompson (2011) we cluster standard errors at both bank and time levels. Table VI presents the estimation results.

In the first column we regress Market to Book Value on our variables of interest, namely Fiduciary, Life Insurance, Other Insurance, Loan Servicing, Loan Sale and Service Charge. We attempt to capture bank-level heterogeneity by including Core Deposit, Credit Risk, Inefficiency, Capital and Market Share in columns (2) to (6), respectively. In column (7), we include state-level control variables, namely, HHI, Home Price Growth and Income Growth. Column (8) displays the result when we scale the non-interest income items by total assets in lieu of total operating income as a robustness check. In all specifications, among various non-interest income activities, Fiduciary depicts a positive relationship with our proxy for Franchise Value. The relationship is also economically significant. Fiduciary activities on average account for about $0.9 \%$ of total operating income. A one percent increase, evaluated at the mean, in the income share of Fiduciary in total net operating income increases Market to Book Value on average, by $15.81 \%$. The average Market to Book Value is $126.7 \%$, so the effect is economically significant and equal to a $12.5 \%\left(12.5 \%=\frac{15.81 \%}{126.7 \%}\right)$ rise in the average Market to Book Value.

The results also show that Core Deposit has a positive association with charter value. Banks with more Credit Risk or Inefficiency have on average lower Franchise Value. 
Moreover, we observe that Franchise Value is higher in states with less concentrated markets, or those which experience greater home price or personal income growth. In columns (9) and (10), we use Tobin's $Q$ as the alternative proxy in lieu of Market to Book Value and reestimate our model with the same specifications as of columns (7) and (8). The results support our previous finding: an increase in the income share of fiduciary activities increases banks' franchise value.

\section{[TABLE VI]}

\subsection{COST COMPLEMENTARITIES}

The linkage of the non-interest income activities with loan quality and spreads may be due to informational and/or cost synergies. In this section, we investigate whether pair-wise cost complementarity exists between lending and the non-interest income activities that might contribute to joint production ${ }^{17}$. As such, we examine whether the marginal cost of producing loans decreases when they are generated jointly with non-interest income activities. Appendix A2 illustrates our multi-product cost function from which marginal costs are derived.

In a multi-product firm the pair-wise cost complementarity (PCC) between two products exists when an increase in product A lowers the marginal cost of producing product B (Clark, 1988). The measure of cost complementarity is as follows:

$$
\operatorname{PCC}\left(Y_{A}, Y_{B}\right)=\frac{\partial^{2} T C}{\partial Y_{A} \partial Y_{B}}=\left(\frac{T C}{Y_{A} Y_{B}}\right) \times\left[\frac{\partial^{2} \operatorname{LnTC}}{\partial \operatorname{Ln} Y_{A} \partial \operatorname{Ln} Y_{B}}+\left(\frac{\partial \operatorname{LnTC}}{\partial \operatorname{Ln} Y_{A}}\right) \times\left(\frac{\partial \operatorname{LnTC}}{\partial \operatorname{Ln} Y_{B}}\right)\right]
$$

PCC $<0$ implies the existence of cost complementarity between products A and B. The necessary condition for the existence of cost complementarity $(\mathrm{PCC}<0)$ is:

$$
N C_{-} P C C=\frac{\partial^{2} L n T C}{\partial \operatorname{LnY} Y_{A} \partial \operatorname{LnY} Y_{B}}<0
$$

\footnotetext{
${ }^{17}$ Informational synergy analysis requires detailed data on clients' relationship which are not available.
} 
PCC $=0$ implies the non-jointness or absence of cost complementarities. At any non-zero production level of $\mathrm{Y}_{\mathrm{A}}$ and $\mathrm{Y}_{\mathrm{B}}, \frac{T C}{Y_{A} Y_{B}}>0$. Hence, non-jointness requires:

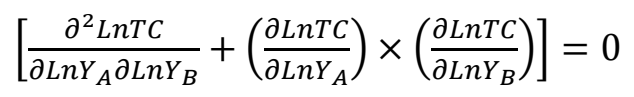

PCC > 0 implies existence of diseconomy of joint production.

Table VII illustrates the empirical results on cost complementarity between the noninterest income activities and lending (secured and unsecured loans (Y1 \& Y2)) for Micro and Non-Micro Commercial Banks. In the first two rows we use stochastic frontier analysis to estimate our cost function which is defined on the basis of the intermediation approach that assumes banks as intermediaries (Berger and Mester, 1997 among others). The first three columns display the analysis of Non-Micro Commercial Banks.

In column (1), the first row, the result shows that the necessary condition for the existence of diseconomies of joint production between non-interest income activities and secured loans is realized, whereas in the second row, we find the necessary condition for the existence of cost complementarity between non-interest income activities and unsecured loans. However, column (2) shows that the sufficiency condition for the existence of diseconomy of joint production or cost complementarity is not fulfilled and highlights non-jointness ${ }^{18}$. In column (3) we observe that the marginal cost of secured loans is around $9.7 \%$ which is greater than the marginal cost of unsecured loans equal to $2.2 \%$.

Columns (4) to (6) exhibit the study of Micro Commercial Banks. In column (4), the findings indicate that the necessary condition for diseconomies of joint production of noninterest income activities with secured and unsecured loans is realized. Column (5) shows that the sufficiency condition for diseconomies of joint production of non-interest income activities

\footnotetext{
${ }^{18}$ Normally total cost is much less than the products of loans (whether Secured or Unsecured) with other financial services (in our case the non-interest income businesses). Hence, the first component of the measure of cost complementarity, $\frac{T C}{Y_{A} Y_{B}}$, is too small such that its product with the second component makes the measure very close to zero, implying non-jointness.
} 
with secured and unsecured loans is fulfilled. The marginal cost of secured and unsecured loans of Micro Commercial Banks, displayed in column (6), is equal to 5.33\% and 5.15\%, respectively. The effect of diseconomies of joint production is economically meaningful. One dollar increase in non-interest income equals $0.12 \%\left(0.12 \%=\frac{0.000063}{0.0533}\right)$ and $0.09 \%$ $\left(0.09 \%=\frac{0.000048}{0.0515}\right)$ increase in the marginal cost of secured and unsecured loans, respectively.

\section{[TABLE VII]}

As a robustness check, we also follow the production approach (Berger and DeYoung, 1997 among others) and include transaction deposits in our model as a further output. The results are presented in rows (3) and (4) and are similar to our previous findings, except for the secured loans of Non-Micro Commercial Banks, where we find that the necessary condition for cost complementarity between secured loans and non-interest income is realized.

In rows (5) to (8), we replicate our analysis in the first four rows using the fixed effect technique for estimation of total cost function in lieu of stochastic frontier analysis. The results are in line with our previous findings. Overall, we find that Micro Commercial Banks suffer from diseconomies of joint production, whereas Non-Micro Commercial Banks do not benefit (or suffer) from economies (or diseconomies) of scope.

\subsection{FURTHER ROBUSTNESS CHECKS}

We find that an increase in income share of fiduciary activities lowers credit risk. As a further robustness check and in order to address endogeneity issues, we estimate our model (Equation (1)) using the two step system GMM technique introduced by Roodman (2006). The technique also performs the Windmeijer (2005) finite-sample correction to the stated standard errors. For this purpose, we focus on the post-crisis period, since we have relatively small time periods which are suitable for application of difference and system GMM 
techniques. Table A3 of the appendix presents the results, where we define Fiduciary as an endogenous variable.

In the first column we observe that Fiduciary appears with a negative coefficient similarly to our previous finding. We run the Arellano and Bond (A.B.) test (1991) for serial correlation in the error terms. The null hypothesis is no auto-correlation in the firstdifferenced residuals at the second order ${ }^{19}$. The A.B. test result does not reject the null hypothesis. We also carry out the Sargan test of over-identification, where the null hypothesis is the joint validity of moment conditions. The Sargan (1958) test result rejects the null hypothesis. In column (4), we limit the instruments of system GMM estimators to the second lag of the dependent variable which reduces the number of instruments from 416 to 234 . This time, the Sargan test rejects the null merely at the ten percent significance level, whereas our finding in the previous column remains almost unchanged. In column (3), we scale the noninterest income items by total assets in lieu of total net operating income. In this specification the result persists and the Sargan test of over-identification does not reject the null hypothesis.

\section{Summary and Conclusion}

This paper analyzes the impact of non-interest income activities on banks' lending in terms of credit quality and spread. Agency problems and a potential loss of focus associated with diversification into non-interest income businesses may cause deterioration in loan quality. Alternatively, expanding client relationships can improve the quality of banks' credit by, providing relatively stable financial resources, more soft information, greater cross-selling opportunities and (ultimately) improved franchise value. Banks with a wider scope of relationships are able to reach more potential borrowers. Moreover, non-interest earnings may also influence banks' interest spread through possible cross-subsidization effects.

\footnotetext{
${ }^{19}$ Rejecting the null hypothesis at the first order does not imply that the moments are not valid, since the first difference of independently and identically distributed errors is serially correlated.
} 
Using quarterly data on 8,287 U.S. commercial banks between 2003 and 2010 we study smaller commercial banks with less than $\$ 100$ million of total assets ('micro' commercial banks) separately from larger institutions that have developed a broader array of non-interest lines of businesses ('non-micro' commercial banks). Overall, our analysis of nonmicro commercial banks shows that an increase in the income share of fiduciary activities in total operating income lowers credit risk. The impact is more pronounced during the postcrisis period. The results suggest that fiduciary activities induce banks' managers to behave more prudently in lending, because such activities increase banks' franchise value as shown by our further investigation. The other non-interest income activities which may be thought to have influence on banks' lending - such as service charges on deposit accounts - do not appear to have any robust relationship with the quality of bank lending.

We find little evidence to support the prevalent view in the literature that there is cross-subsidization between traditional intermediation and non-interest income activities except for fiduciary in the post-crisis period where we observe that a higher income share of fiduciary activities is associated with lower lending-deposit spreads.

The analysis of micro commercial banks provides us with little evidence of any link between our non-interest income variables and credit risk. Finally, we investigate whether pair-wise cost complementarity or alternatively diseconomies of joint production exist between lending (both secured and unsecured) and non-interest income activities. We do not find any evidence to support the existence of cost complementarity. Our results even show that micro commercial banks actually suffer from diseconomies of joint production. 


\section{Appendices}

\section{Table A1. Variable Description}

This table presents description of variables used in this study.

\begin{tabular}{|c|c|}
\hline Dependent Variables & Description \\
\hline Non-performing Loans & $\begin{array}{l}\text { The ratio of non-performing loans to gross loans. Non-performing loans consist of non-accrual loans and } \\
\text { loans which are past due for } 90 \text { days or more and still accruing. }\end{array}$ \\
\hline Loan Loss Reserve & $\begin{array}{l}\text { The ratio of loan loss reserves to gross loans. Loan loss reserve is determined by managers for the loan } \\
\text { portfolio, including both performing and impaired loans. }\end{array}$ \\
\hline Loan Loss Provision & $\begin{array}{l}\text { The ratio of loan loss provision to average gross loans. Loan loss provision is the expense that banks } \\
\text { incur to increase the loan loss reserve or writing off a loan. It can be negative, when the required loan } \\
\text { loss reserve is lower than the existing level. }\end{array}$ \\
\hline Risk Weighted Assets & $\begin{array}{l}\text { The ratio of risk weighted assets to total assets. Risk weighted assets are defined by the Basel Accord to } \\
\text { measure the riskiness of banks' assets, including off balance sheet items. }\end{array}$ \\
\hline Spread & $\begin{array}{l}\text { Net interest spread equals to (Interest income / average earning assets) - (interest expense / average } \\
\text { interest-bearing liabilities). }\end{array}$ \\
\hline Market to Book Value & The market value of equity capital divided by total book value of equity capital. \\
\hline Tobin's $Q$ & $\begin{array}{l}\text { The market value of equity capital plus the book value of total liabilities divided by the book value of } \\
\text { total assets. }\end{array}$ \\
\hline \multicolumn{2}{|l|}{ Variable of Interest } \\
\hline Fiduciary & Income from fiduciary activities. \\
\hline Life Insurance & $\begin{array}{l}\text { Earnings on/increase in value of cash surrender value of life insurance plus fees and commissions from } \\
\text { annuity sales. }\end{array}$ \\
\hline Other Insurance Services & $\begin{array}{l}\text { Underwriting income from insurance and reinsurance activities and income from other insurance } \\
\text { activities. }\end{array}$ \\
\hline Loan Servicing & Net servicing fees. \\
\hline Loan Sale & Net gains (losses) on sales of loans and leases and net securitization income. \\
\hline Service Charge & $\begin{array}{l}\text { Service charges on deposit accounts in domestic offices, income and fees from the printing and sale of } \\
\text { checks, income and fees from automated teller machines and bank card and credit card interchange fees. }\end{array}$ \\
\hline \multicolumn{2}{|l|}{ Control Variables } \\
\hline Capital & Equity capital to asset ratio. \\
\hline Inefficiency & Total non-interest expense divided by total operating revenue. \\
\hline Core Deposit & The share of core deposits in total liabilities. \\
\hline Liquid Asset & The ratio of liquid assets to total liabilities. \\
\hline Interest Rate Risk & The difference between the annualized federal funds rate and the implicit interest rate of deposits. \\
\hline Loan Commitment & The ratio of face value of unused credit lines and loans commitment to total assets. \\
\hline Loan Growth & Quarterly growth rate of gross loans. \\
\hline Wage & The salaries and employee benefits divided by number of full time equivalent employees. \\
\hline Market Share & The share of a bank's total assets in the total assets of banks aggregated at the state-level. \\
\hline Size & Logarithm of total assets. \\
\hline $\log ($ Age $)$ & Logarithm of bank's age. \\
\hline$H H I$ & 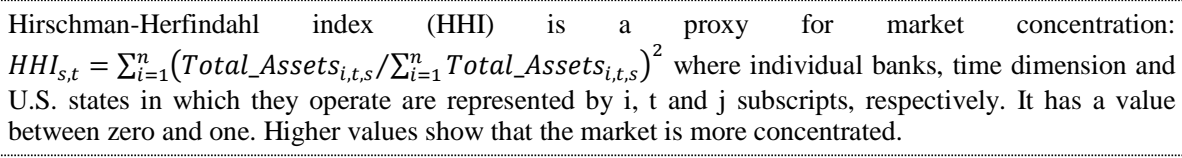 \\
\hline Home Price Index Growth & $\begin{array}{l}\text { Quarterly growth rate of home price index per state, retrieved from the Office of Federal Housing } \\
\text { Enterprise Oversight. }\end{array}$ \\
\hline Personal Income Growth & Quarterly growth rate in personal income per state, collected from Bureau of Economic Analysis. \\
\hline \multicolumn{2}{|c|}{ Other Non-interest Income Activities } \\
\hline Venture Capital & Venture capital revenue. \\
\hline Securities Brokerage & Fees and commission from securities brokerage. \\
\hline Investment Banking & Investment banking, advisory, and underwriting fees and commissions. \\
\hline Trading & $\begin{array}{l}\text { Trading revenue and net change in the fair values of financial instruments accounted for under a fair } \\
\text { value option. }\end{array}$ \\
\hline
\end{tabular}


Other Assets Sales
Net gains (losses) on sales of other real estate owned, net gains (losses) on sales of other assets (excluding securities), rent and other income from other real estate owned.

Other non-interest income. 
Appendix A2. Cost Complementarities Analysis - Cost Function \& Descriptive Statistics

Using the intermediation approach (Berger and Mester, 1997 among others), we set-up the following multi-product cost function with a trans-logarithmic functional form (Berndt and Christensen, 1973):

$$
\begin{aligned}
\operatorname{LnTC}= & C_{0}+\sum_{i=1}^{6} \alpha_{i} \operatorname{Ln} Y_{i}+\sum_{j=1}^{3} \beta_{j} \operatorname{Ln} W_{j}+\gamma_{1} \operatorname{LnZ}+\tau_{1} \text { Trend } \\
& +\frac{1}{2}\left[\sum_{i=1}^{6} \sum_{k=1}^{6} \delta_{i, k} \operatorname{LnY}_{i} \operatorname{Ln} Y_{k}+\sum_{j=1}^{3} \sum_{l=1}^{3} \theta_{j, l} \operatorname{LnW}_{j} \operatorname{Ln} W_{l}+\gamma_{2}(\text { LnZ })^{2}+\tau_{2} \text { Trend }^{2}\right] \\
& +\sum_{i=1}^{6} \sum_{j=1}^{3} \mu_{i, j} \operatorname{Ln} Y_{i} \operatorname{Ln} W_{j}+\sum_{i=1}^{6} \vartheta_{i} \operatorname{Ln} Y_{i} \operatorname{LnZ}+\sum_{i=1}^{6} \pi_{i} \operatorname{LnY}_{i} \operatorname{Trend}_{+}+\sum_{j=1}^{3} \varphi_{j} \operatorname{LnW}_{j} \operatorname{LnZ} \\
& +\sum_{j=1}^{3} \sigma_{j} \operatorname{Ln} W_{j} \text { Trend }+\varepsilon
\end{aligned}
$$

Wherein $T C$ is the total costs including total interest and non-interest expenses; $\mathrm{Y}$ is the output vector consisting of:

$\mathrm{Y} 1=$ loans secured on real estate,

Y2 = loans unsecured,

Y3 = securities plus federal funds sold and securities purchased under agreements to resell,

Y4 = total nominal value of off-balance sheet items,

Y5 = the income from the non-interest income activities (Fiduciary, Life Insurance, Other

Insurance Services and Loan Servicing),

Y6 $=$ the income from service charges on deposit accounts;

$\mathrm{W}$ is the input price vector comprising:

$\mathrm{W} 1$ = salary expenses divided by the number of full-time equivalent employees,

$\mathrm{W} 2=$ expenses of premises and fixed assets divided by total fixed assets,

$\mathrm{W} 3=$ total interest expense divided by interest-bearing liabilities. 
$\mathrm{Z}$ is the total capital equity and is added to the model to control for unmeasured cost of equity capital. Banks with higher equity capital have lower total costs as they have less debt financing and hence interest expense, assuming all other factors equal (Hughes and Mester, 2013).

We consider the homogeneity and symmetry assumptions which require:

$\sum_{j=1}^{3} \beta_{j}=1, \sum_{j=1}^{3} \sum_{l=1}^{3} \theta_{j, l}=0, \quad \sum_{i=1}^{6} \sum_{j=1}^{3} \mu_{i, j}=0, \sum_{j=1}^{3} \varphi_{j}=0$

$\delta_{i, k}=\delta_{k, i}$ and $\theta_{j, l}=\theta_{l, j}$ for all $i, k, j$ and $l$

We also impose input price homogeneity restrictions (an increase in all input prices increases the total costs by the same percentage) on the cost function parameters by dividing all input prices (W1 and W2) and total costs (TC) with one other factor price (W3).

The total cost function is estimated using a stochastic frontier approach introduced by Aigner et al. (1977) which fits the cost function to best practice banks. This approach assumes that the error term $(\varepsilon)$ has two components which are independently distributed: One idiosyncratic error (or random noise) term with a symmetric distribution (v) and the inefficiency term with a strictly nonnegative distribution (u). We assume that the inefficiency component follows a time-varying decay model proposed by Battese and Coelli (1992), so $\exp \left\{-\eta\left(t-T_{i}\right)\right\} u_{i}$. $T_{i}$ is the last period in the $i^{\text {th }}$ panel and $\eta$ is the parameter to be estimated. Table A2 presents the descriptive statistics of the total costs, output and input price vectors and total equity capital for Micro and Non-Micro Commercial Banks. 
TABLE A2. Cost Complementarities Analysis - Descriptive Statistics

This table presents general descriptive statistics of total costs, output vectors, input price vectors and capital equity for Micro and Non-Micro Commercial Banks. Micro Commercial Banks are defined as banks with less than $\$ 100$ million in total assets. Non-Micro Commercial Banks are commercial banks with total assets above $\$ 100$ million.

\begin{tabular}{|c|c|c|c|c|c|c|c|c|c|c|}
\hline \multirow[t]{2}{*}{ Variables } & \multicolumn{5}{|c|}{ Non-Micro Commercial Banks } & \multicolumn{5}{|c|}{ Micro Commercial Banks } \\
\hline & Obs & Mean & Std. Dev. & Min & $\operatorname{Max}$ & Obs & Mean & Std. Dev. & Min & $\operatorname{Max}$ \\
\hline $\mathrm{TC}$ & 96,467 & 73,245 & 419,831 & 2,240 & $5,958,665$ & 37,668 & 3,112 & 1,404 & 331 & 9,753 \\
\hline Y1 & 96,467 & 610,398 & $2,858,554$ & 1,948 & $37,300,000$ & 37,668 & 25,814 & 15,838 & 375 & 86,568 \\
\hline $\mathrm{Y} 2$ & 96,467 & 264,756 & $1,974,595$ & 3 & $29,100,000$ & 37,668 & 4,723 & 5,959 & 2 & 37,054 \\
\hline Y3 & 96,467 & 322,192 & $1,784,309$ & 575 & $25,200,000$ & 37,668 & 16,673 & 11,261 & 62 & 68,285 \\
\hline Y4 & 96,467 & 417,532 & $4,549,868$ & 10 & $74,000,000$ & 37,668 & 1,401 & 2,077 & 1 & 15,817 \\
\hline Y5 & 96,467 & 7,717 & 79,940 & 1 & $1,418,112$ & 37,668 & 73 & 169 & 1 & 3,680 \\
\hline Y6 & 96,467 & 6,840 & 41,682 & 9 & 586,454 & 37,668 & 263 & 199 & 3 & 1,321 \\
\hline Y7 & 96,467 & 136,053 & 616,435 & 452 & $8,637,374$ & 37,668 & 15,820 & 8,587 & 143 & 53,050 \\
\hline W1 (\%) & 96,467 & 56.44 & 16.32 & 26.91 & 179 & 37,668 & 50.22 & 12.09 & 22.86 & 126 \\
\hline $\mathrm{W} 2(\%)$ & 96,467 & 30.33 & 35.49 & 4.81 & 588 & 37,668 & 37.51 & 51.97 & 3.74 & 1,067 \\
\hline W3 (\%) & 96,467 & 2.46 & 0.87 & 0.38 & 5.08 & 37,668 & 2.41 & 0.80 & 0.45 & 5.00 \\
\hline $\mathrm{Z}$ & 96,467 & 168,069 & $1,035,367$ & 4,123 & $14,800,000$ & 37,668 & 6,702 & 3,155 & 705 & 23,550 \\
\hline
\end{tabular}

$T C$ is the total costs including total interest and non-interest expenses; $\mathrm{Y} 1=$ Loans secured by real estate; Y2 $=$ Loans unsecured on real estate; Y3 = Securities plus federal funds sold and securities purchased under agreements to resell; Y4 = total off-balance sheet items; Y5 = the non-interest income activities, including Fiduciary, Life Insurance, Other Insurance Services and Loan Servicing; Y6 = Service Charge; Y7 = Total transaction accounts (including total demand deposits); W1 = salary expenses divided by number of full-time equivalent employees; W2 = expenses of premises and fixed assets divided by total fixed assets; $\mathrm{W} 3=$ total interest expense divided by interest-bearing liabilities. $\mathrm{Z}=$ the total capital equity. Total costs (TC), output vectors (Ys) and capital equity (Z) are in million $\$$ and the input prices (Ws) are in percentage. 


\section{Table A3. Credit Risk Model - Further Robustness Checks}

This table reports estimations of Credit Risk model (Equation (1)) using dynamic panel setting and quarterly data on 3,489 Non-Micro Commercial Banks during the post-crisis period. Non-Micro Commercial Banks are defined as commercial banks with total assets above \$100 million. We use Non-performing Loans as our Credit Risk proxy and regress it on its lagged value, our variables of interest and a set of control variables. We estimate our model using two step system GMM technique introduced by Roodman (2006) and define our variable of interest, i.e. Fiduciary, as endogenous.

The first column illustrates the estimation of Credit Risk model where we regress the Non-performing Loans on Fiduciary, Life Insurance, Other Insurance Services, Loan Servicing, Loan Sale and Service Charge while controlling for bank-level (Capital, Inefficiency, Risk Weighted Assets, Loan Commitment, Loan Growth, Size and Log(Age)) and state-level (HHI, Home Price Growth and Income Growth) heterogeneities and year 2010 dummy.

We perform the Arellano and Bond (AB) test (1991) for serial correlation in the error terms and Sargan test of overidentification, where the null hypothesis is joint validity of moment conditions. The Sargan (1958) J test result rejects the null hypothesis. In column (2), we limit the instruments of system GMM estimators to the second lag of dependent variable to reduce the number of instruments from 416 to 234. The results show that Sargan test rejects the null merely at 10 percent significance level. In column (3) we scale the non-interest income items by total assets in lieu of total net operating income and estimate our model the same specifications and techniques used in the column.

\begin{tabular}{|c|c|c|c|}
\hline & (1) & (2) & (3) \\
\hline L. Credit Risk $\left(\alpha_{1}\right)$ & $\begin{array}{c}0.924 * * * \\
(90.88)\end{array}$ & $\begin{array}{c}0.921 * * * \\
(76.00)\end{array}$ & $\begin{array}{c}0.916^{* * * *} \\
(75.16)\end{array}$ \\
\hline Fiduciary $\left(\alpha_{21}\right)$ & $\begin{array}{c}-0.029 * * \\
(-2.48)\end{array}$ & $\begin{array}{c}-0.032 * * * \\
(-2.65)\end{array}$ & $\begin{array}{c}-0.902 * * * \\
(-3.56)\end{array}$ \\
\hline Life Insurance $\left(\alpha_{22}\right)$ & $\begin{array}{c}-0.020 * * \\
(-2.28)\end{array}$ & $\begin{array}{l}-0.013 \\
(-1.57)\end{array}$ & $\begin{array}{c}-0.454 * * \\
(-2.16)\end{array}$ \\
\hline Other Insurance $\left(\alpha_{23}\right)$ & $\begin{array}{c}-0.020 * * * \\
(-3.44)\end{array}$ & $\begin{array}{c}-0.018 * * * \\
(-3.16)\end{array}$ & $\begin{array}{c}-0.259 * * \\
(-2.21)\end{array}$ \\
\hline Loan Servicing $\left(\alpha_{24}\right)$ & $\begin{array}{l}-0.007 \\
(-0.92)\end{array}$ & $\begin{array}{l}-0.009 \\
(-1.18)\end{array}$ & $\begin{array}{l}-0.117 \\
(-0.73)\end{array}$ \\
\hline Loan Sale Income $\left(\alpha_{25}\right)$ & $\begin{array}{c}-0.008 * * * \\
(-2.88)\end{array}$ & $\begin{array}{c}-0.006^{* *} \\
(-2.03)\end{array}$ & $\begin{array}{c}-0.096 * \\
(-1.65)\end{array}$ \\
\hline Service Charge $\left(\alpha_{26}\right)$ & $\begin{array}{c}-0.005 * * * \\
(-2.65)\end{array}$ & $\begin{array}{c}-0.005 * * * \\
(-2.89)\end{array}$ & $\begin{array}{c}-0.169 * * * \\
(-5.50)\end{array}$ \\
\hline Capital $\left(\alpha_{3}\right)$ & $\begin{array}{c}-0.030 * * * \\
(-6.50)\end{array}$ & $\begin{array}{c}-0.030 * * * \\
(-6.96)\end{array}$ & $\begin{array}{c}-0.031 * * * \\
(-7.06)\end{array}$ \\
\hline Inefficiency $\left(\alpha_{4}\right)$ & $\begin{array}{c}0.006^{* * * *} \\
(7.29)\end{array}$ & $\begin{array}{c}0.006^{* * * *} \\
(6.44)\end{array}$ & $\begin{array}{c}0.006^{* * * *} \\
(6.21)\end{array}$ \\
\hline Risk Weighted Assets $\left(\alpha_{5}\right)$ & $\begin{array}{c}0.004 * * * \\
(3.59)\end{array}$ & $\begin{array}{c}0.003 * * * \\
(3.15)\end{array}$ & $\begin{array}{c}0.003 \text { *** } \\
(3.44)\end{array}$ \\
\hline Loan Commitment $\left(\alpha_{6}\right)$ & $\begin{array}{c}-0.013 * * * \\
(-4.49)\end{array}$ & $\begin{array}{c}-0.012 * * * \\
(-3.89)\end{array}$ & $\begin{array}{c}-0.012 * * * \\
(-3.94)\end{array}$ \\
\hline Loan Growth $\left(\alpha_{7}\right)$ & $\begin{array}{c}0.012 * * * \\
(3.76)\end{array}$ & $\begin{array}{c}0.013 * * * \\
(4.12)\end{array}$ & $\begin{array}{c}0.012 * * * \\
(3.79)\end{array}$ \\
\hline Size $\left(\alpha_{8}\right)$ & $\begin{array}{c}0.104^{* * * *} \\
(8.03)\end{array}$ & $\begin{array}{c}0.099 * * * \\
(7.56)\end{array}$ & $\begin{array}{c}0.106 \text { *** } \\
(8.30)\end{array}$ \\
\hline $\log ($ Age $)\left(\alpha_{9}\right)$ & $\begin{array}{c}-0.050 * * * \\
(-4.45)\end{array}$ & $\begin{array}{c}-0.050 * * * \\
(-4.75)\end{array}$ & $\begin{array}{c}-0.049 * * * \\
(-4.72)\end{array}$ \\
\hline $\mathrm{HHI}\left(\alpha_{10}\right)$ & $\begin{array}{c}0.201 * * * \\
(3.41)\end{array}$ & $\begin{array}{c}0.179 * * * \\
(3.25)\end{array}$ & $\begin{array}{c}0.164 \text { *** } \\
(2.97)\end{array}$ \\
\hline Home Price Growth $\left(\alpha_{11}\right)$ & $\begin{array}{c}-0.021 * * * \\
(-3.57)\end{array}$ & $\begin{array}{c}-0.022 * * * \\
(-3.78)\end{array}$ & $\begin{array}{c}-0.020 * * * \\
(-3.58)\end{array}$ \\
\hline Income Growth $\left(\alpha_{12}\right)$ & $\begin{array}{c}-0.076 * * * \\
(-12.58)\end{array}$ & $\begin{array}{c}-0.059 * * * \\
(-9.01)\end{array}$ & $\begin{array}{c}-0.064 * * * \\
(-9.73)\end{array}$ \\
\hline Year $2010\left(\alpha_{13,7}\right)$ & $\begin{array}{c}0.086^{* * * *} \\
(4.63)\end{array}$ & $\begin{array}{c}0.125 * * * \\
\quad(6.69)\end{array}$ & $\begin{array}{c}0.125 * * * \\
(6.66)\end{array}$ \\
\hline Constant $\left(\alpha_{0}\right)$ & $\begin{array}{c}0.204 * * * \\
(14.34)\end{array}$ & $\begin{array}{c}0.182 * * * \\
(11.37)\end{array}$ & $\begin{array}{c}0.185 \text { *** } \\
(11.49)\end{array}$ \\
\hline Observations & 23,211 & 23,211 & 23,211 \\
\hline Number of Banks & 3,489 & 3,489 & 3,489 \\
\hline $\mathrm{AB}$ test for $\mathrm{AR}(1)$ & $-21.97 * * *$ & $-20.71 * * *$ & $-20.65 * * *$ \\
\hline $\mathrm{AB}$ test for $\mathrm{AR}(2)$ & -0.17 & -0.10 & -0.13 \\
\hline Sargan Test & $762 * * *$ & $242 *$ & 238 \\
\hline Number of Instruments & 416 & 234 & 234 \\
\hline
\end{tabular}

See Table A1 for variable definitions. ***, ** and $*$ indicate significance at $1 \%, 5 \%$ and $10 \%$ respectively. 


\section{References}

Aigner, D., Lovell, C. A. K. and Schmidt, P. (1977) Formulation and estimation of stochastic frontier production function models, Journal of Econometrics 6, 21-37.

Akhigbe, A and Stevenson, B.A. (2010) Profit efficiency in U.S. BHCs: Effects of increasing non-traditional revenue sources, The Quarterly Review of Economics and Finance 50, 132-140.

Alessandri, P. and Drehmann, M. (2010) An economic capital model integrating credit and interest rate risk in the banking book, Journal of Banking \& Finance 34, 730-742.

Anderson, T. and Hsiao, C. (1981) Estimation of dynamic models with error components, Journal of the American Statistical Association 76(375), 598-606.

Arellano, M. and Bond, S. (1991) Some tests of specification for panel data: Monte Carlo evidence and an application to employment equations, Review of Economic Studies 58, 277-297.

Bank for International Settlements (2010) 80th Annual Report, June, Basel.

Battese, G. E., and Coelli, T. J. (1992) Frontier production functions, technical efficiency and panel data: With application to paddy farmers in India, Journal of Productivity Analysis 3, 153-169.

Berg, T., Saunders, A. and Steffen, S. (2013) The total cost of corporate borrowing in the loan market: Don't forget the fees, Working Paper.

Berger, A.N. (1995) The profit structure relationship in banking: Tests of market-power and efficient-structure hypotheses, Journal of Money, Credit, and Banking 27, 404-431.

Berger, A.N. (1999) The 'Big Picture' of relationship finance, in business access to capital and credit (J.L. Blanton, A. Williams and S.L. Rhine, Eds.), pp. 390-400, A Federal Reserve System Research Conference.

Berger, A.N. and DeYoung, R. (1997) Problem Loans and cost efficiency in commercial banks, Journal of Banking \& Finance 21, 849-870.

Berger, A.N. and Mester, L.J. (1997) Inside the black box: What explains differences in the efficiencies of financial institutions?, Journal of Banking \& Finance 21, 895-947.

Berndt, E. and Christensen, L. (1973) The translog function and the substitution of equipment, structures, and labor in U.S. manufacturing 1929-68, Journal of Econometrics 1, 81-144.

Boot, A.W.A. (2000) Relationship banking: What do we know?, Journal of Financial Intermediation 9, 7-25.

Boot, A.W.A. (2003) Consolidation and strategic positioning in banking with implications for Europe, Working Paper.

Borio, C. and Zhu, H. (2008) Capital regulation, risk-taking and monetary policy: A missing link in the transmission mechanism?, Bank for International Settlements Working Paper No. 268.

Brunnermeier, M., Dong, G. and Palia, D. (2011) Banks non-interest income and systemic risk. Working Paper, 2011.

Carbo, S. and Rodriguez, F. (2007) The determinants of bank margins in European banking, Journal of Banking \& Finance 31, 2043-2063. 
Carling, K., Jacobson, T., Linde, J. and Roszbach, K. (2007) Corporate credit risk modeling and the macroeconomy, Journal of Banking \& Finance 31, 845-868.

Clair, R. (1992) Loan growth and loan quality: Some preliminary evidence from Texas banks, Federal Reserve Bank of Dallas Economic Review, 3rd quarter, 9-22.

Clark, J.A. (1988) Economies of scale and scope at depository financial institutions: A review of the literature, Economic Review, September/October 1988, 16-33.

Degryse, H. and Cayseele, P.V. (2000) Relationship lending within a bank-based system: Evidence from European small business data, Journal of Financial Intermediation 9, 90109.

De Jonghe, O (2010) Back to the basics in banking? A micro-analysis of banking system stability. Journal of Financial Intermediation 19, 387-417.

De Jonghe, O. and Vennet, R.V. (2008) Competition versus efficiency: What drives franchise values in European banking?, Journal of Banking \& Finance 32, 1820-1835.

Delis, M.D. and Kouretas, G.P. (2011) Interest rates and bank risk-taking, Journal of Banking \& Finance 35, 840-855.

Dell'Ariccia, G. and Marquez, R. (2006) Lending booms and lending standards, The Journal of Finance 61, 2511-2546.

Demirguc-Kunt, A. and Huizinga, H. (2010) Bank activity and funding strategies: the impact on risk and returns. Journal of Financial Economics 98, 626-650.

Demsetz, R., Saidenberg, M., Strahan, P. (1996) Banks with something to lose: The disciplinary role of franchise value, Federal Reserve Bank of New York Economic Policy Review 2, 1-14.

DeYoung, R. and Rice, T. (2004) Noninterest income and financial performance at U.S. commercial banks, The Financial Review 39, 101-127.

DeYoung R. and Roland, K. P. (2001) Product mix and earnings volatility at commercial banks: Evidence from a degree of total leverage model, Journal of Financial Intermediation 10, 54-84.

DeYoung, R. And Torna, G. (2013) Nontraditional banking activities and bank failures during the financial crisis, Journal of Financial Intermediation 22, 397-421.

Diamond, D. (1984) Financial intermediation and delegated monitoring, Review of Economic Studies 51, 393-414.

Drehmann, M., Sorensen, S. and Stringa, M. (2010) The integrated impact of credit and interest rate risk on banks: A dynamic framework and stress testing application, Journal of Banking \& Finance 34, 735-751.

Elyasiani, E. and Wang, Y. (2009) Non-interest income diversification and information asymmetry of bank holding companies, Working Paper.

Federal Deposit Insurance Corporation (2012) Community banking study, December.

Fiordelisi, F., Marques-Ibanez, D. and Molyneux, P. (2011) Efficiency and risk in European banking, Journal of Banking \& Finance 35, 1315-1326.

Foos, D., Norden, L. and Weber, M. (2010) Loan Growth and riskiness of banks, Journal of Banking \& Finance 34, 2929-2940. 
Gonzalez, F. (2005) Bank regulation and risk taking incentives: An international comparison of bank risk, Journal of Banking \& Finance 29, 1153-1184.

Hansen, L.P. (1982) Large Sample properties of generalized method of moments estimators, Econometrica 50, 1029-1054.

Hellmann, T., Lindsey, L. and Puri, M. (2008) Building relationships early: banks in venture capital, The Review of Financial Studies 21, 513-541.

Hughes, J.P., Mester, L.J. and Moon, C. (2001) Are scale economies in banking elusive or illusive: Evidence obtained by incorporating capital structure and risk-taking into models of bank production, Journal of Banking \& Finance 25, 2169-2208.

Hughes, J.P. and Mester, L.J. (2013) Who said large banks don't experience scale economies? Evidence from a risk-return-driven cost function, Journal of Financial Intermediation, http://dx.doi.org/10.1016/j.jfi.2013.06.004.

Independent Commission on Banking (2011) "Vickers Report" The, Final Report, Recommendations, September, HMSO: London.

International Monetary Fund (2011) Making banks safer: Can Volcker and Vickers do it?, IMF Working Paper, November.

Jacques, K. and Nigro, P. (1997) Risk-based capital, portfolio risk, and bank capital: A simultaneous equations approach, Journal of Economics and Business 49, 533-47.

Jarrow, R.A. and Turnbull, S.M. (2000) The intersection of market and credit risk, Journal of Banking \& Finance 24, 271-299.

Kane, E. (2010) Redefining and containing systemic risk, Atlantic Economic Journal 38, 251264.

Keeley, M.C. (1990) Deposit insurance, risk and market power in banking, American Economic Review 80, 1183-1200.

Kwan, S. and Eisenbeis, R. (1997) Bank risk, capitalization and operating efficiency, Journal of Financial Services Research 12, 117-31.

Laeven, L. and Levine, R. (2007) Is there a diversification discount in financial conglomerates?, Journal of Financial Economics 85, 331-367.

Lepetit, L., Nys, E., Rous, P. and Tarazi, A. (2008a) Bank income structure and risk: An empirical analysis of European banks, Journal of Banking \& Finance 32, 1452-1467.

Lepetit, L., Nys, E., Rous, P. and Tarazi, A. (2008b) The expansion of services in European banking: Implications for loan pricing and interest margins, Journal of Banking \& Finance 32, 2325-2335.

Liikanen, E. (2012) High-level Expert Group on Reforming the Structure of the EU Banking Sector, Brussels, 2 October 2012.

Loutskina, E. (2011) The role of securitization in bank liquidity and funding management, Journal of Financial Economics 100, 663-684.

Marcus, A. J. (1984) Deregulation and bank financial policy, Journal of Banking \& Finance 8, 557-565.

Maudos, J. and De Guevara, J.F. (2004) Factors explaining the interest margin in the banking sectors of the European Union, Journal of Banking \& Finance 28, 2259-2281. 
McShane, R.W. and Sharpe, I.G. (1985) A time series/cross section analysis of the determinants of Australian trading bank loan/deposit interest margins: 1962-1981, Journal of Banking \& Finance 9, 115-136.

Moshirian, F., Sahgal, S. and Zhang, B. (2011) Non-interest income and systemic risk: The role of concentration, working paper.

Ogura, Y. (2006) Learning from a rival bank and lending boom, Journal of Financial Intermediation 15, 535-555.

Opler, T. and Titman, S. (1994) Financial distress and corporate performance, The Journal of Finance 49, 1015-1040.

Petersen, M.A. (2009) Estimating standard errors in finance panel data sets: Comparing approaches, The Review of Financial Studies 22, 435-480.

Petersen, M.A. and Rajan, R.G. (1995) The effect of credit market competition on lending relationships, Quarterly Journal of Economics 110, 406-443.

Puri, M., Rochell, J. and Steffen, S. (2011) On the importance of prior relationships in bank loans to retail customers, ECB Working Paper No. 1395.

Rajan, R.G. (2006) Has finance made the world riskier?, European Financial Management 12, 499-533.

Rime, B. (2001) Capital requirements and bank behaviour: Empirical evidence for Switzerland, Journal of Banking \& Finance 25, 789-805.

Roodman, D. (2006) How to do xtabond2: An introduction to difference and system GMM in Stata, Center for Global Development, working paper number 103, December 2006.

Roodman, D. (2009) How to do xtabond2: An introduction to difference and system GMM in Stata, Stata Journal 9, 86-136.

Sargan, J.D. (1958) The estimation of economic relationships using instrumental variables, Econometrica 26, 393-415.

Saunders, A. and Schumacher, L. (2000) The determinants of bank interest rate margins: An international study, Journal of International Money and Finance 19, 813-832.

Shrieves, R.E. and Dahl, D. (1992) The relationship between risk and capital in commercial banks, Journal of Banking \& Finance 16, 439-57.

Stiroh, K. (2004) Diversification in banking: Is non-interest income the answer?, Journal of Money, Credit and Banking 36, 853-882.

Stiroh, K. (2006) A portfolio view of banking with interest and noninterest activities, Journal of Money, Credit and Banking 38, 1351-1361.

Stiroh, K. and Rumble, A. (2006) The dark side of diversification: The case of US financial holding companies, Journal of Banking \& Finance 30, 2131-2161.

Thompson, S.B. (2011) Simple formulas for standard errors that cluster by both firm and time, Journal of Financial Economics 99, 1-10.

Wagner, D. (2009) AP IMPACT: Government mortgage partners sued for abuses, Associated Press, August 06, 2009.

Windmeijer, F. (2005) A finite sample correction for the variance of linear efficient two-step GMM estimators, Journal of Econometrics 126, 25-51. 
Table I. Descriptive Statistics

PANEL A. Bank-level Indicators

This table illustrates general descriptive statistics of U.S. commercial banks for the period of 2003-2010. Non-Micro Commercial Banks are defined as commercial banks with total assets above \$100 million. Micro Commercial Banks are defined as banks with less than $\$ 100$ million in total assets.

\begin{tabular}{|c|c|c|c|c|c|c|c|c|c|c|c|c|}
\hline & \multirow[b]{2}{*}{ Variable } & \multicolumn{5}{|c|}{ Non-Micro Commercial Banks } & \multicolumn{5}{|c|}{ Micro Commercial Banks } & \multirow[b]{2}{*}{ T-Stat. $\dagger$} \\
\hline & & Obs & Mean & Std. Dev. & Min & Max & Obs & Mean & $\begin{array}{l}\text { Std. } \\
\text { Dev. }\end{array}$ & Min & Max & \\
\hline \multirow{17}{*}{ 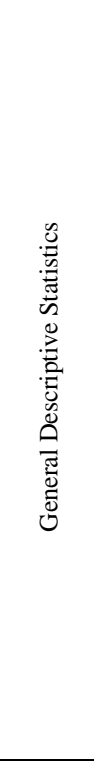 } & Total Assets (mil. \$) & 130,884 & 1,364 & 8,203 & 6.06 & 126,000 & 80,277 & 55 & 27 & 5.96 & 816 & $57.7 * * *$ \\
\hline & Non-performing Loans (\%) & 130,868 & 1.12 & 2.13 & 0.00 & 13.86 & 80,188 & 0.92 & 1.65 & 0.00 & 10.44 & $24.3 * * *$ \\
\hline & Loan Loss Reserve (\%) & 130,868 & 1.44 & 0.75 & 0.00 & 5.46 & 80,188 & 1.55 & 0.89 & 0.00 & 6.85 & $-28.8 * * *$ \\
\hline & Loan Loss Provision (\%) & 130,871 & 0.56 & 0.98 & -0.81 & 6.18 & 80,188 & 0.35 & 0.75 & -1.88 & 4.74 & $53.6 * * *$ \\
\hline & Risk Weighted Assets (\%) & 130,884 & 71.73 & 12.97 & 1.23 & 106.24 & 80,277 & 65.32 & 13.99 & 0.39 & 126.69 & $104.9 * * *$ \\
\hline & Spread (\%) & 130,884 & 3.54 & 0.87 & 0.69 & 7.71 & 80,267 & 3.67 & 0.85 & 0.62 & 8.05 & $-31.5 * * *$ \\
\hline & Capital (\%) & 130,884 & 10.07 & 3.06 & 0.01 & 25.71 & 80,277 & 11.46 & 3.97 & 0.11 & 30.41 & $-84.9 * * *$ \\
\hline & Inefficiency (\%) & 130,727 & 67.10 & 18.89 & 0.80 & 167.16 & 80,237 & 72.14 & 20.56 & 0.00 & 194.28 & $-56.4 * * *$ \\
\hline & Core Deposits (\%) & 130,884 & 71.24 & 15.03 & 0.00 & 99.99 & 80,277 & 78.56 & 12.72 & 0.00 & 100.00 & $-120 * * *$ \\
\hline & Liquid Assets (\%) & 130,884 & 25.95 & 16.17 & 0.00 & 95.08 & 80,277 & 32.47 & 19.93 & 0.00 & 122.10 & $-78.2 * * *$ \\
\hline & Interest Rate Risk (\%) & 130,687 & -0.15 & 1.52 & -3.71 & 5.26 & 80,144 & -0.09 & 1.59 & -3.49 & 5.25 & $-9.13 * * *$ \\
\hline & Loan Commitment (\%) & 130,884 & 3.47 & 4.50 & 0.00 & 26.13 & 80,277 & 1.42 & 2.58 & 0.00 & 14.74 & $132.5^{* * *}$ \\
\hline & Loan Growth (\%) & 130,860 & 2.02 & 5.37 & -19.09 & 30.00 & 80,262 & 1.25 & 6.11 & -24.27 & 33.13 & $29.2 * * *$ \\
\hline & Wage (thou. \$) & 130,739 & 58.31 & 18.30 & 0.04 & 150.18 & 80,194 & 51.50 & 14.20 & 0.44 & 126.09 & $95.6^{* * * *}$ \\
\hline & Age & 130,884 & 65.59 & 44.77 & 3.00 & 227.00 & 80,277 & 75.99 & 37.11 & 3.00 & 171.75 & $-57.7 * * *$ \\
\hline & Market Share (\%) & 130,884 & 0.70 & 1.73 & 0.00 & 10.92 & 80,277 & 0.08 & 0.09 & 0.00 & 0.64 & $129.9 * * *$ \\
\hline & Non-interest Income (\%) & 130,729 & 17.53 & 11.68 & -21.75 & 80.71 & 80,237 & 14.08 & 8.91 & -15.18 & 62.23 & $76.6^{* * * *}$ \\
\hline \multirow{6}{*}{ 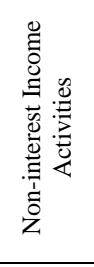 } & Fiduciary Activities (\%) & 130,729 & 0.90 & 2.48 & 0.00 & 15.06 & 80,237 & 0.06 & 0.29 & 0.00 & 1.79 & $120.7 * * *$ \\
\hline & Life Insurance (\%) & 130,729 & 0.64 & 1.06 & 0.00 & 6.47 & 80,237 & 0.40 & 1.00 & 0.00 & 5.88 & $51.4 * * *$ \\
\hline & Insurance Services (\%) & 130,729 & 0.43 & 1.24 & -5.71 & 7.42 & 80,237 & 0.47 & 1.30 & -0.18 & 7.77 & $-5.74 * * *$ \\
\hline & Loans Servicing (\%) & 130,729 & 0.41 & 1.15 & -2.41 & 6.76 & 80,237 & 0.21 & 0.77 & -0.31 & 4.79 & $49 * * *$ \\
\hline & Loan Sales (\%) & 130,729 & 1.46 & 3.51 & -3.03 & 20.75 & 80,237 & 0.36 & 1.38 & -0.64 & 8.22 & $101.4 * * *$ \\
\hline & Service Charges $(\%)$ & 130,729 & 8.40 & 5.43 & -20.23 & 38.32 & 80,237 & 8.62 & 5.27 & -1.32 & 36.07 & $-9.02 * * *$ \\
\hline \multirow{5}{*}{ 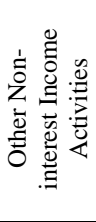 } & Securities Brokerage (\%) & 62,787 & 0.28 & 0.67 & -2.87 & 4.02 & 38,065 & 0.04 & 0.20 & 0.00 & 1.21 & $81.7 * * *$ \\
\hline & Investment Banking (\%) & 62,787 & 0.09 & 0.33 & 0.00 & 1.93 & 38,065 & 0.01 & 0.04 & 0.00 & 0.26 & $59.7 * * *$ \\
\hline & Trading (\%) & 130,729 & 0.01 & 0.06 & -0.06 & 0.40 & 80,237 & 0.00 & 0.00 & 0.00 & 0.00 & $54.9 * * *$ \\
\hline & Other Assets Sales (\%) & 130,729 & -0.14 & 1.83 & -10.01 & 9.40 & 80,237 & 0.01 & 1.45 & -7.87 & 8.02 & $-20.6^{* * *}$ \\
\hline & Other Activities (\%) & 130,729 & 4.45 & 5.02 & -0.18 & 32.51 & 80,237 & 3.11 & 3.58 & 0.00 & 22.55 & $71.6^{* * *}$ \\
\hline \multirow{2}{*}{ 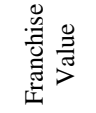 } & Market to Book Ratio (\%) & 2,836 & 126.7 & 60.27 & 0.01 & 368.5 & 615 & 99.2 & 52.24 & 2.53 & 278.9 & $11.5^{* * *}$ \\
\hline & Tobin’s Q (\%) & 2,836 & 102.9 & 6.56 & 83.30 & 137.2 & 615 & 100.2 & 5.85 & 88.75 & 123.2 & $10.0 * * *$ \\
\hline
\end{tabular}

$\dagger$ T-Stat. of mean equality test between Non-Micro Commercial and Commercial banks. $* * *, * *$ and $*$ indicate significance at $1 \%, 5 \%$ and $10 \%$ respectively. See Table AI for variable definitions.

PANEL B. State-level Indicators

This panel shows the summary statistics of HHI, the growth rate of home price index and personal income across 51 U.S. states during the 2003-2010 period.

\begin{tabular}{lccccc}
\hline Variable & Obs & Mean & Std. Dev. & Min & Max \\
\hline HHI (\%) & 1,472 & 0.19 & 0.19 & 0.01 & 0.96 \\
Home Price Index Growth (\%) & 1,248 & 0.55 & 2.32 & -12.94 & 11.10 \\
Income Growth (\%) & 1,248 & 1.06 & 1.33 & -4.30 & 6.00 \\
\hline
\end{tabular}

See Table A1 for variable definitions. 


\section{Table II. Credit Risk Model}

This table reports estimations of Credit Risk model (Equation (1)) using quarterly data of 5,106 Non-Micro Commercial Banks and 2,792 Micro Commercial Banks during 2003-2010 timespan. Non-Micro Commercial Banks are defined as commercial banks with total assets above $\$ 100$ million, whereas Micro Commercial Banks are banks with less than $\$ 100$ million in total assets. We use Non-performing Loans as our primary Credit Risk proxy and regress it on our variables of interest and a set of control variables, using dynamic panel setting and fixed effect technique.

In columns (1) to (7), we estimate the model for Non-Micro Commercial Banks. In the first four columns we use Nonperforming Loans as a proxy for Credit Risk. Column (1) illustrates the estimation of Credit Risk model where we regress the Credit Risk proxy on Fiduciary Activities, Life Insurance, Other Insurance Services, Loan Servicing, Loan Sale Income and Service Charge while controlling for Capital, Inefficiency and Risk Weighted Assets and year fixed effect controls. In column (2), we try to capture heterogeneities caused by loan portfolio management by adding Loan Commitment and Loan Growth. Size and $\log ($ Age $)$ are included in the third column. We introduce state-level variables, i.e. HHI, Home Price Growth and Income Growth in column (4). In columns (5) to (7), we estimate our model, where we use Loan Loss Reserve, Loan Loss Provision and Risk Weighted Assets in lieu of Non-performing Loans as alternative proxies for Credit Risk. Finally, column (8) displays the estimations of our model for Micro Commercial Banks, wherein Non-performing Loans is used as the Credit Risk proxy. Year dummies are included in the model, but not reported in the table.

\begin{tabular}{|c|c|c|c|c|c|c|c|c|}
\hline & \multicolumn{7}{|c|}{ Non-Micro Banks } & \multirow{2}{*}{$\begin{array}{c}\text { Micro Banks } \\
\begin{array}{c}\text { Non-Performing } \\
\text { Loans }\end{array}\end{array}$} \\
\hline & $\begin{array}{l}\text { Non-Performing } \\
\text { Loans }\end{array}$ & $\begin{array}{l}\text { Non-Performing } \\
\text { Loans }\end{array}$ & $\begin{array}{l}\text { Non-Performing } \\
\text { Loans }\end{array}$ & $\begin{array}{l}\text { Non-Performing } \\
\text { Loans }\end{array}$ & $\begin{array}{l}\text { Loan Loss } \\
\text { Reserve }\end{array}$ & $\begin{array}{l}\text { Loan Loss } \\
\text { Provision }\end{array}$ & $\begin{array}{l}\text { Risk Weighted } \\
\text { Assets }\end{array}$ & \\
\hline Variables & (1) & (2) & (3) & (4) & (5) & (6) & (7) & (8) \\
\hline L. Credit Risk $\left(\alpha_{1}\right)$ & $\begin{array}{l}0.884 * * * \\
(222.97)\end{array}$ & $\begin{array}{l}0.876 * * * \\
(216.50)\end{array}$ & $\begin{array}{c}0.872 * * * \\
(213.42)\end{array}$ & $\begin{array}{l}0.877 * * * \\
(204.57)\end{array}$ & $\begin{array}{c}0.860 * * * \\
(153.41)\end{array}$ & $\begin{array}{c}0.668 * * * \\
(91.09)\end{array}$ & $\begin{array}{l}0.790 * * * \\
(157.77)\end{array}$ & $\begin{array}{c}0.710 \text { **** } \\
(86.18)\end{array}$ \\
\hline Fiduciary $\left(\alpha_{21}\right)$ & $\begin{array}{c}-0.013 * * * \\
(-2.59)\end{array}$ & $\begin{array}{c}-0.013 * * \\
(-2.53)\end{array}$ & $\begin{array}{c}-0.012 * * \\
(-2.36)\end{array}$ & $\begin{array}{c}-0.010 * * \\
(-2.02)\end{array}$ & $\begin{array}{c}-0.004 * * \\
(-2.17)\end{array}$ & $\begin{array}{c}-0.011 * * * \\
(-2.73)\end{array}$ & $\begin{array}{c}-0.039^{*} \\
(-1.77)\end{array}$ & $\begin{array}{l}-0.019 \\
(-0.76)\end{array}$ \\
\hline Life Insurance $\left(\alpha_{22}\right)$ & $\begin{array}{l}-0.003 \\
(-0.67)\end{array}$ & $\begin{array}{l}-0.004 \\
(-0.85)\end{array}$ & $\begin{array}{l}-0.003 \\
(-0.58)\end{array}$ & $\begin{array}{l}-0.006 \\
(-1.13)\end{array}$ & $\begin{array}{l}0.001 \\
(0.55)\end{array}$ & $\begin{array}{l}0.005 \\
(1.35)\end{array}$ & $\begin{array}{l}-0.004 \\
(-0.22)\end{array}$ & $\begin{array}{l}0.003 \\
(0.38)\end{array}$ \\
\hline Other Insurance $\left(\alpha_{23}\right)$ & $\begin{array}{c}-0.009 * * \\
(-2.07)\end{array}$ & $\begin{array}{c}-0.008^{* *} \\
(-1.98)\end{array}$ & $\begin{array}{l}-0.008^{*} \\
(-1.89)\end{array}$ & $\begin{array}{c}-0.008^{* *} \\
(-1.98)\end{array}$ & $\begin{array}{l}-0.003 * \\
(-1.79)\end{array}$ & $\begin{array}{l}-0.006 \\
(-1.52)\end{array}$ & $\begin{array}{l}0.023 \\
(1.00)\end{array}$ & $\begin{array}{l}-0.009 \\
(-1.51)\end{array}$ \\
\hline Loan Servicing $\left(\alpha_{24}\right)$ & $\begin{array}{l}0.001 \\
(0.25)\end{array}$ & $\begin{array}{l}0.002 \\
(0.36)\end{array}$ & $\begin{array}{l}0.002 \\
(0.31)\end{array}$ & $\begin{array}{l}0.001 \\
(0.28)\end{array}$ & $\begin{array}{l}-0.002 \\
(-0.79)\end{array}$ & $\begin{array}{l}-0.007 \\
(-1.43)\end{array}$ & $\begin{array}{l}-0.003 \\
(-0.13)\end{array}$ & $\begin{array}{l}0.015 \\
(1.27)\end{array}$ \\
\hline Loan Sale Income $\left(\alpha_{25}\right)$ & $\begin{array}{c}-0.004 * * \\
(-2.53)\end{array}$ & $\begin{array}{c}-0.004 * * \\
(-2.55)\end{array}$ & $\begin{array}{c}-0.004 * * \\
(-2.54)\end{array}$ & $\begin{array}{l}-0.002 \\
(-1.40)\end{array}$ & $\begin{array}{c}-0.001 * * * \\
(-2.59)\end{array}$ & $\begin{array}{l}0.000 \\
(0.24)\end{array}$ & $\begin{array}{l}0.008 \\
(1.28)\end{array}$ & $\begin{array}{l}0.006 \\
(1.01)\end{array}$ \\
\hline Service Charge $\left(\alpha_{26}\right)$ & $\begin{array}{c}-0.008 * * * \\
(-4.10)\end{array}$ & $\begin{array}{c}-0.008 * * * \\
(-4.20)\end{array}$ & $\begin{array}{c}-0.005 * * \\
(-2.51)\end{array}$ & $\begin{array}{c}-0.004 * \\
(-1.76)\end{array}$ & $\begin{array}{l}-0.001 \\
(-0.74)\end{array}$ & $\begin{array}{l}0.001 \\
(0.55)\end{array}$ & $\begin{array}{c}-0.044 * * * \\
(-4.96)\end{array}$ & $\begin{array}{l}0.004 \\
(1.54)\end{array}$ \\
\hline Capital $\left(\alpha_{3}\right)$ & $\begin{array}{c}-0.023 * * * \\
(-8.97)\end{array}$ & $\begin{array}{c}-0.023 * * * \\
(-8.93)\end{array}$ & $\begin{array}{c}-0.020 * * * \\
(-7.90)\end{array}$ & $\begin{array}{c}-0.020 * * * \\
(-7.48)\end{array}$ & $\begin{array}{c}-0.010 * * * \\
(-9.38)\end{array}$ & $\begin{array}{c}-0.027 * * * \\
(-10.65)\end{array}$ & $\begin{array}{c}0.105^{* * * *} \\
(7.81)\end{array}$ & $\begin{array}{c}-0.019 * * * \\
(-5.01)\end{array}$ \\
\hline Inefficiency $\left(\alpha_{4}\right)$ & $\begin{array}{c}0.007 * * * \\
(15.51)\end{array}$ & $\begin{array}{c}0.007 * * * \\
(15.43)\end{array}$ & $\begin{array}{c}0.007 * * * \\
(16.09)\end{array}$ & $\begin{array}{c}0.007 * * * * \\
(14.89)\end{array}$ & $\begin{array}{c}0.002 * * * \\
(12.84)\end{array}$ & $\begin{array}{c}0.006 * * * \\
(16.08)\end{array}$ & $\begin{array}{l}0.002 \\
(1.42)\end{array}$ & $\begin{array}{c}0.005^{* * * *} \\
(9.87)\end{array}$ \\
\hline Risk Weighted Assets $\left(\alpha_{5}\right)$ & $\begin{array}{c}-0.002 * * \\
(-1.98)\end{array}$ & $\begin{array}{c}0.002 * * \\
(2.05)\end{array}$ & $\begin{array}{c}0.002 * * * \\
(2.80)\end{array}$ & $\begin{array}{l}0.001 \\
(1.55)\end{array}$ & $\begin{array}{l}0.000 \\
(0.27)\end{array}$ & $\begin{array}{c}0.001 * * \\
(1.97)\end{array}$ & & $\begin{array}{c}0.002 * * \\
(2.30)\end{array}$ \\
\hline Loan Commitment $\left(\alpha_{6}\right)$ & & $\begin{array}{c}-0.020 * * * \\
(-10.50)\end{array}$ & $\begin{array}{c}-0.019 * * * \\
(-10.50)\end{array}$ & $\begin{array}{c}-0.019 * * * \\
(-9.83)\end{array}$ & $\begin{array}{c}-0.004 * * * \\
(-7.02)\end{array}$ & $\begin{array}{c}-0.012 * * * \\
(-8.11)\end{array}$ & $\begin{array}{c}0.266 * * * \\
(28.89)\end{array}$ & $\begin{array}{c}-0.013 * * * \\
(-4.21)\end{array}$ \\
\hline Loan Growth $\left(\alpha_{7}\right)$ & & $\begin{array}{c}-0.008 * * * * \\
(-10.22)\end{array}$ & $\begin{array}{c}-0.007 * * * \\
(-9.89)\end{array}$ & $\begin{array}{c}-0.006 * * * \\
(-7.94)\end{array}$ & $\begin{array}{c}-0.009 * * * \\
(-24.19)\end{array}$ & $\begin{array}{c}-0.006 * * * \\
(-11.37)\end{array}$ & $\begin{array}{c}0.130 * * * \\
(29.82)\end{array}$ & $\begin{array}{c}-0.007 \text { *** } \\
(-8.89)\end{array}$ \\
\hline $\operatorname{Size}\left(\alpha_{8}\right)$ & & & $\begin{array}{c}0.191 * * * \\
(8.21)\end{array}$ & $\begin{array}{c}0.183 * * * \\
(7.49)\end{array}$ & $\begin{array}{c}0.036^{* * * *} \\
(4.25)\end{array}$ & $\begin{array}{c}0.110 * * * \\
(5.86)\end{array}$ & $\begin{array}{c}-1.781 * * * \\
(-12.65)\end{array}$ & $\begin{array}{l}0.048 \\
(0.94)\end{array}$ \\
\hline $\log ($ Age $)\left(\alpha_{9}\right)$ & & & $\begin{array}{c}0.276 * * * \\
(7.10)\end{array}$ & $\begin{array}{c}0.253 * * * \\
(6.09)\end{array}$ & $\begin{array}{c}0.062 * * * \\
(4.77)\end{array}$ & $\begin{array}{c}0.143 * * * \\
(5.16)\end{array}$ & $\begin{array}{c}1.316^{* * * *} \\
(7.90)\end{array}$ & $\begin{array}{c}0.535 * * * * \\
(6.95)\end{array}$ \\
\hline $\mathrm{HHI}\left(\alpha_{10}\right)$ & & & & $\begin{array}{l}0.036 \\
(0.65)\end{array}$ & $\begin{array}{l}0.010 \\
(0.50)\end{array}$ & $\begin{array}{l}-0.051 \\
(-1.13)\end{array}$ & $\begin{array}{l}0.106 \\
(0.47)\end{array}$ & $\begin{array}{l}0.010 \\
(0.15)\end{array}$ \\
\hline Home Price Growth $\left(\alpha_{11}\right)$ & & & & $\begin{array}{c}-0.020 * * * \\
(-7.85)\end{array}$ & $\begin{array}{c}-0.004 * * * \\
(-4.49)\end{array}$ & $\begin{array}{c}-0.012 * * * \\
(-6.09)\end{array}$ & $\begin{array}{c}-0.033 * * * \\
(-3.90)\end{array}$ & $\begin{array}{c}-0.026 * * * \\
(-6.34)\end{array}$ \\
\hline Income Growth $\left(\alpha_{12}\right)$ & & & & $\begin{array}{c}-0.015 * * * \\
(-6.23)\end{array}$ & $\begin{array}{c}-0.004 * * * \\
(-4.78)\end{array}$ & $\begin{array}{l}0.001 \\
(0.34)\end{array}$ & $\begin{array}{l}-0.011 \\
(-1.25)\end{array}$ & $\begin{array}{l}-0.002 \\
(-0.55)\end{array}$ \\
\hline Constant $\left(\alpha_{0}\right)$ & $\begin{array}{c}-0.131 * * * \\
(-24.13)\end{array}$ & $\begin{array}{c}-0.134 * * * \\
(-23.96)\end{array}$ & $\begin{array}{c}-0.048 * * * \\
(-5.71)\end{array}$ & $\begin{array}{c}-0.019 * \\
(-1.94)\end{array}$ & $\begin{array}{l}0.002 \\
(0.66)\end{array}$ & $\begin{array}{c}-0.033 * * * \\
(-4.55)\end{array}$ & $\begin{array}{c}-0.782 * * * \\
(-14.57)\end{array}$ & $\begin{array}{c}-0.035 * * * \\
(-2.60)\end{array}$ \\
\hline Observations & 125,211 & 125,211 & 125,211 & 108,630 & 108,630 & 108,632 & 108,644 & 71,094 \\
\hline R-squared & 0.830 & 0.831 & 0.831 & 0.837 & 0.786 & 0.595 & 0.726 & 0.583 \\
\hline Number of Banks & 5,106 & 5,106 & 5,106 & 4,371 & 4,371 & 4,371 & 4,371 & 2,792 \\
\hline
\end{tabular}

See Table A1 for variable definitions. Standard errors are adjusted for clusters in banks. ***, ** and * indicate significance at $1 \%, 5 \%$ and $10 \%$ respectively. 


\section{Table III. Spread Model}

This table reports estimations of the Spread model (Equation (2)) using quarterly data of 5,106 Non-Micro Commercial Banks and 2,788 Micro Commercial Banks during 2003-2010 period. Non-Micro Commercial Banks are defined as commercial banks with total assets above $\$ 100$ million, whereas Micro Commercial Banks are banks with less than $\$ 100$ million in total assets.

We use net interest spread (Spread) defined as [(total interest income/average total earning assets) - (total interest expense/average total interest-bearing liabilities)] for our study. Columns (1) to (5) present our analysis of Non-Micro Banks. In the first column, we regress Spread on our variables of interest, i.e. Fiduciary Activities, Life Insurance, Other Insurance Services, Loan Servicing, Loan Sale and Service Charge which are scaled by total assets in lieu of total operating income, while controlling for Capital, Inefficiency and year fixed effects. In column (2), we introduce Loan Loss Provision, Liquid Assets and Interest Rate Risk to our model. We add Core Deposit, Loan Commitment and Wage to our analysis in column (3). Size and $\log ($ Age) are included in the fourth column. Column (5) displays the result when we control for state-level heterogeneity by introducing HHI, Home Price Growth and Income Growth. In column (6), we analyse the sub-sample of Micro Banks and use the same specification presented in column (5). We estimate our model using fixed effect technique. Year dummies are included in the model, but not reported in the table.

\begin{tabular}{|c|c|c|c|c|c|c|}
\hline \multirow[b]{2}{*}{ Variables } & \multicolumn{5}{|c|}{ Non-Micro Banks } & \multirow{2}{*}{$\frac{\text { Micro Banks }}{(6)}$} \\
\hline & (1) & (2) & (3) & (4) & (5) & \\
\hline L. Spread $\left(\beta_{1}\right)$ & $\begin{array}{c}0.766 * * * \\
(136.65)\end{array}$ & $\begin{array}{c}0.748 * * * \\
(132.72)\end{array}$ & $\begin{array}{c}0.739 * * * \\
(126.33)\end{array}$ & $\begin{array}{c}0.736 * * * \\
(126.09)\end{array}$ & $\begin{array}{c}0.735^{* * * *} \\
(114.41)\end{array}$ & $\begin{array}{c}0.705^{* * * *} \\
(91.48)\end{array}$ \\
\hline Fiduciary $\left(\beta_{21}\right)$ & $\begin{array}{c}0.078^{*} \\
(1.88)\end{array}$ & $\begin{array}{l}0.063 \\
(1.57)\end{array}$ & $\begin{array}{l}0.055 \\
(1.36)\end{array}$ & $\begin{array}{l}0.011 \\
(0.24)\end{array}$ & $\begin{array}{l}0.005 \\
(0.10)\end{array}$ & $\begin{array}{c}0.402 * \\
(1.86)\end{array}$ \\
\hline Life Insurance $\left(\beta_{22}\right)$ & $\begin{array}{c}0.142 * * * \\
(3.67)\end{array}$ & $\begin{array}{c}0.127 * * * \\
(3.41)\end{array}$ & $\begin{array}{c}0.109 * * * \\
(2.91)\end{array}$ & $\begin{array}{c}0.075^{* * *} \\
(2.00)\end{array}$ & $\begin{array}{c}0.091 \text { ** } \\
(2.43)\end{array}$ & $\begin{array}{l}-0.013 \\
(-0.25)\end{array}$ \\
\hline Other Insurance $\left(\beta_{23}\right)$ & $\begin{array}{c}0.146^{* * * *} \\
(3.06)\end{array}$ & $\begin{array}{c}0.111^{* *} \\
(2.25)\end{array}$ & $\begin{array}{c}0.092 * \\
(1.71)\end{array}$ & $\begin{array}{l}0.076 \\
(1.36)\end{array}$ & $\begin{array}{c}0.111 * \\
(1.88)\end{array}$ & $\begin{array}{l}0.117 \\
(1.35)\end{array}$ \\
\hline Loan Servicing $\left(\beta_{24}\right)$ & $\begin{array}{l}0.068 \\
(1.60)\end{array}$ & $\begin{array}{l}0.060 \\
(1.45)\end{array}$ & $\begin{array}{l}0.041 \\
(0.93)\end{array}$ & $\begin{array}{l}0.034 \\
(0.76)\end{array}$ & $\begin{array}{l}0.054 \\
(1.13)\end{array}$ & $\begin{array}{l}0.075 \\
(0.86)\end{array}$ \\
\hline Loan Sale Income $\left(\beta_{25}\right)$ & $\begin{array}{c}0.044 * * * \\
(3.51)\end{array}$ & $\begin{array}{c}0.038 * * * \\
(3.13)\end{array}$ & $\begin{array}{c}0.032 * * \\
(2.57)\end{array}$ & $\begin{array}{c}0.031 * * \\
(2.47)\end{array}$ & $\begin{array}{c}0.024^{*} \\
(1.94)\end{array}$ & $\begin{array}{l}-0.052 \\
(-1.21)\end{array}$ \\
\hline Service Charge $\left(\beta_{26}\right)$ & $\begin{array}{c}0.249 * * * \\
(13.74)\end{array}$ & $\begin{array}{c}0.239 * * * \\
(13.73)\end{array}$ & $\begin{array}{c}0.240 * * * \\
(13.66)\end{array}$ & $\begin{array}{c}0.193 * * * \\
(10.99)\end{array}$ & $\begin{array}{c}0.183 * * * \\
(9.89)\end{array}$ & $\begin{array}{c}0.140 * * * \\
(5.71)\end{array}$ \\
\hline Capital $\left(\beta_{3}\right)$ & $\begin{array}{c}0.015^{* * * *} \\
(14.29)\end{array}$ & $\begin{array}{c}0.017 * * * \\
(16.10)\end{array}$ & $\begin{array}{c}0.016^{* * * *} \\
(15.52)\end{array}$ & $\begin{array}{c}0.015^{* * *} * \\
(14.60)\end{array}$ & $\begin{array}{c}0.015^{* * * *} \\
(13.96)\end{array}$ & $\begin{array}{c}0.013 * * * \\
(8.43)\end{array}$ \\
\hline Inefficiency $\left(\beta_{4}\right)$ & $\begin{array}{c}-0.004 * * * \\
(-24.56)\end{array}$ & $\begin{array}{c}-0.004 * * * * \\
(-25.73)\end{array}$ & $\begin{array}{c}-0.004 * * * \\
(-26.24)\end{array}$ & $\begin{array}{c}-0.005^{* * *} * \\
(-27.60)\end{array}$ & $\begin{array}{c}-0.005^{* * *} \\
(-25.64)\end{array}$ & $\begin{array}{c}-0.006^{* * * *} \\
(-24.46)\end{array}$ \\
\hline Loan Loss Provision $\left(\beta_{5}\right)$ & & $\begin{array}{c}0.012 * * * \\
(5.03)\end{array}$ & $\begin{array}{c}0.012 * * * \\
(5.22)\end{array}$ & $\begin{array}{c}0.014 * * * \\
(5.94)\end{array}$ & $\begin{array}{c}0.017 * * * \\
(6.52)\end{array}$ & $\begin{array}{c}0.021 * * * \\
(6.72)\end{array}$ \\
\hline Liquid Assets $\left(\beta_{6}\right)$ & & $\begin{array}{c}-0.006^{* * * *} \\
(-25.62)\end{array}$ & $\begin{array}{c}-0.006 * * * \\
(-25.30)\end{array}$ & $\begin{array}{c}-0.006^{* * * *} \\
(-25.40)\end{array}$ & $\begin{array}{c}-0.006 * * * \\
(-23.25)\end{array}$ & $\begin{array}{c}-0.007 * * * * \\
(-14.22)\end{array}$ \\
\hline Interest Rate Risk $\left(\beta_{7}\right)$ & & $\begin{array}{l}0.001 \\
(0.38)\end{array}$ & $\begin{array}{l}0.003 \\
(0.87)\end{array}$ & $\begin{array}{l}0.000 \\
(0.14)\end{array}$ & $\begin{array}{c}0.004 \\
(1.10)\end{array}$ & $\begin{array}{c}0.041 * * * \\
(7.17)\end{array}$ \\
\hline Core Deposit $\left(\beta_{8}\right)$ & & & $\begin{array}{c}0.001 * * * \\
(6.41)\end{array}$ & $\begin{array}{c}0.001 * * * \\
(5.27)\end{array}$ & $\begin{array}{c}0.001 * * * \\
(3.97)\end{array}$ & $\begin{array}{c}0.002 * * * \\
(4.22)\end{array}$ \\
\hline Loan Commitment $\left(\beta_{9}\right)$ & & & $\begin{array}{c}0.003 * * * \\
(4.98)\end{array}$ & $\begin{array}{c}0.003 * * * \\
(5.42)\end{array}$ & $\begin{array}{c}0.003^{* * * *} \\
(4.90)\end{array}$ & $\begin{array}{l}0.001 \\
(0.70)\end{array}$ \\
\hline Wage $\left(\beta_{10}\right)$ & & & $\begin{array}{c}0.003 * * * \\
(11.26)\end{array}$ & $\begin{array}{c}0.003 * * * \\
(12.21)\end{array}$ & $\begin{array}{c}0.003 * * * \\
(9.95)\end{array}$ & $\begin{array}{c}0.004 * * * \\
(10.92)\end{array}$ \\
\hline Size $\left(\beta_{11}\right)$ & & & & $\begin{array}{c}-0.112 * * * \\
(-10.67)\end{array}$ & $\begin{array}{c}-0.113 * * * \\
(-10.36)\end{array}$ & $\begin{array}{c}-0.220 * * * \\
(-11.66)\end{array}$ \\
\hline $\log ($ Age $)\left(\beta_{12}\right)$ & & & & $\begin{array}{c}0.027 * * \\
(2.26)\end{array}$ & $\begin{array}{c}0.044 * * * \\
(3.43)\end{array}$ & $\begin{array}{c}0.054 * * \\
(2.52)\end{array}$ \\
\hline HHI $\left(\beta_{13}\right)$ & & & & & $\begin{array}{l}0.038 \\
(1.64)\end{array}$ & $\begin{array}{l}0.050 * \\
(1.82)\end{array}$ \\
\hline Home Price Growth $\left(\beta_{14}\right)$ & & & & & $\begin{array}{c}0.004 * * * \\
(4.58)\end{array}$ & $\begin{array}{l}-0.001 \\
(-1.13)\end{array}$ \\
\hline Income Growth $\left(\beta_{15}\right)$ & & & & & $\begin{array}{c}-0.005^{* * * *} \\
(-4.06)\end{array}$ & $\begin{array}{c}-0.017 * * * \\
(-12.48)\end{array}$ \\
\hline Constant $\left(\beta_{0}\right)$ & $\begin{array}{c}0.011 * * * \\
(4.70)\end{array}$ & $\begin{array}{c}0.042 * * * \\
(11.10)\end{array}$ & $\begin{array}{c}0.062^{* * * *} \\
(14.26)\end{array}$ & $\begin{array}{c}0.034 * * * \\
(6.74)\end{array}$ & $\begin{array}{c}0.027 * * * \\
(4.05)\end{array}$ & $\begin{array}{c}0.079 * * * \\
(9.16)\end{array}$ \\
\hline Observations & 125,225 & 125,024 & 124,893 & 124,893 & 108,407 & 70,949 \\
\hline R-squared & 0.732 & 0.739 & 0.741 & 0.743 & 0.742 & 0.732 \\
\hline Number of Banks & 5,106 & 5,102 & 5,095 & 5,095 & 4,362 & 2,788 \\
\hline
\end{tabular}

See Table A1 for variable definitions. Standard errors are adjusted for clusters in banks. $* * *, * *$ and $*$ indicate significance at $1 \%, 5 \%$ and $10 \%$ respectively. 
Table IV. Further Issues - Crisis and post-crisis periods

This table reports estimations of Credit Risk and Spread models (Equations (1) \& (2)) using quarterly data of 4,371 NonMicro Commercial Banks during 2003-2010 timespan. Non-Micro Commercial Banks are defined as commercial banks with total assets above $\$ 100$ million. Columns (1) to (4) illustrate our Credit Risk analysis and column (5) displays the estimation of the Spread model. We define three dummy variables, representing pre, acute and post-crisis periods (Pre, Acute and Post) and use Acute and Post in lieu of year dummies. We replace Fiduciary with it its interaction terms with Pre, Acute and Post.

In the first column, we use Non-performing Loans as our primary proxy for Credit Risk and regress it on our variables of interest (Pre $\times$ Fiduciary, Acute $\times$ Fiduciary and Post $\times$ Fiduciary), the rest of non-interest income items (Life Insurance, Other Insurance Services, Loan Servicing, Loan Sale Income and Service Charge) and a set of bank-level state-level control variables, i.e. Capital, Inefficiency, Risk Weighted Assets, Loan Commitment, Loan Growth, Size, Log(Age), HHI, Home Price Growth and Income Growth. In column (2), Non-performing Loans is replaced by Loan Loss Reserve. We use Loan Loss Provision as the Credit Risk proxy in the third column. In column (4), Risk Weighted Assets as a more generic proxy is studied.

Column (5) displays the regression analysis of our Spread model, wherein the non-interest income items are scaled by total assets in lieu of total net operating income. We regress Spread on Pre $\times$ Fiduciary, Acute $\times$ Fiduciary and Post $\times$ Fiduciary), the rest of non-interest income activities (Life Insurance, Other Insurance Services, Loan Servicing, Loan Sale Income and Service Charge) and a set of bank-level state-level control variables, i.e. Capital, Inefficiency, Loan Commitment, Loan Loss Provision, Liquid Assets, Interest Rate Risk, Core Deposit, Wage, Size, Log(Age), HHI, Home Price Growth and Income Growth. We estimate our model using dynamic panel setting and fixed effect technique.

\begin{tabular}{|c|c|c|c|c|c|}
\hline & $\begin{array}{l}\text { Non-performing } \\
\text { Loans }\end{array}$ & $\begin{array}{l}\text { Loan Loss } \\
\text { Reserve }\end{array}$ & $\begin{array}{c}\text { Loan Loss } \\
\text { Provision }\end{array}$ & $\begin{array}{c}\text { Risk Weighted } \\
\text { Assets }\end{array}$ & Spread \\
\hline & (1) & (2) & (3) & (4) & (5) \\
\hline L.Y & $\begin{array}{l}0.883^{* * * *} \\
(210.25)\end{array}$ & $\begin{array}{l}0.863^{* * * *} \\
(155.79)\end{array}$ & $\begin{array}{c}0.669 * * * \\
(89.44)\end{array}$ & $\begin{array}{l}0.803 * * * \\
(175.83)\end{array}$ & $\begin{array}{l}0.754 * * * \\
(127.20)\end{array}$ \\
\hline PrexFiduciary & $\begin{array}{l}-0.008 \\
(-1.63)\end{array}$ & $\begin{array}{c}-0.006 * * * \\
(-3.24)\end{array}$ & $\begin{array}{c}-0.016^{* * * *} \\
(-3.75)\end{array}$ & $\begin{array}{l}-0.001 \\
(-0.04)\end{array}$ & $\begin{array}{l}-0.026 \\
(-0.57)\end{array}$ \\
\hline AcutexFiducicary & $\begin{array}{c}-0.014 * * * \\
(-2.67)\end{array}$ & $\begin{array}{c}-0.004 * \\
(-1.92)\end{array}$ & $\begin{array}{c}-0.010^{* *} \\
(-2.45)\end{array}$ & $\begin{array}{l}-0.029 \\
(-1.45)\end{array}$ & $\begin{array}{l}0.057 \\
(1.16)\end{array}$ \\
\hline Post $\times$ Fiducicary & $\begin{array}{c}-0.015^{* * * *} \\
(-2.82)\end{array}$ & $\begin{array}{c}-0.004 * * \\
(-2.00)\end{array}$ & $\begin{array}{c}-0.019 * * * \\
(-3.75)\end{array}$ & $\begin{array}{c}-0.051 * * \\
(-2.17)\end{array}$ & $\begin{array}{l}-0.091 * \\
(-1.69)\end{array}$ \\
\hline Life Insurance & $\begin{array}{l}0.005 \\
(1.06)\end{array}$ & $\begin{array}{l}0.002 \\
(1.12)\end{array}$ & $\begin{array}{c}0.008 * * \\
(2.08)\end{array}$ & $\begin{array}{c}0.029 * \\
(1.65)\end{array}$ & $\begin{array}{l}-0.016 \\
(-0.43)\end{array}$ \\
\hline Other Insurance & $\begin{array}{c}-0.010 * * \\
(-2.27)\end{array}$ & $\begin{array}{l}-0.003 * \\
(-1.91)\end{array}$ & $\begin{array}{l}-0.006 \\
(-1.43)\end{array}$ & $\begin{array}{l}0.022 \\
(0.97)\end{array}$ & $\begin{array}{c}0.128 * * \\
(2.19)\end{array}$ \\
\hline Loan Servicing & $\begin{array}{l}0.004 \\
(0.76)\end{array}$ & $\begin{array}{l}-0.001 \\
(-0.60)\end{array}$ & $\begin{array}{l}-0.005 \\
(-0.94)\end{array}$ & $\begin{array}{l}-0.005 \\
(-0.22)\end{array}$ & $\begin{array}{l}0.031 \\
(0.65)\end{array}$ \\
\hline Loan Sale & $\begin{array}{l}-0.000 \\
(-0.18)\end{array}$ & $\begin{array}{l}-0.001 \\
(-1.57)\end{array}$ & $\begin{array}{l}0.002 * * \\
(2.05)\end{array}$ & $\begin{array}{l}-0.005 \\
(-0.79)\end{array}$ & $\begin{array}{l}0.014 \\
(1.11)\end{array}$ \\
\hline Service Charge & $\begin{array}{l}-0.001 \\
(-0.38)\end{array}$ & $\begin{array}{l}0.000 \\
(0.14)\end{array}$ & $\begin{array}{c}0.003 * * \\
(2.00)\end{array}$ & $\begin{array}{c}-0.040 * * * \\
(-4.81)\end{array}$ & $\begin{array}{c}0.170 * * * \\
(9.41)\end{array}$ \\
\hline Capital & $\begin{array}{c}-0.018 * * * \\
(-6.71)\end{array}$ & $\begin{array}{c}-0.010 * * * \\
(-9.63)\end{array}$ & $\begin{array}{c}-0.027 * * * \\
(-10.83)\end{array}$ & $\begin{array}{c}0.121^{* * * *} \\
(9.23)\end{array}$ & $\begin{array}{c}0.014 * * * \\
(12.72)\end{array}$ \\
\hline Inefficiency & $\begin{array}{c}0.007 * * * \\
(15.63)\end{array}$ & $\begin{array}{c}0.002 * * * \\
(13.01)\end{array}$ & $\begin{array}{c}0.006^{* * * *} \\
(16.73)\end{array}$ & $\begin{array}{c}0.005^{* * * *} \\
(3.16)\end{array}$ & $\begin{array}{c}-0.005 * * * \\
(-26.24)\end{array}$ \\
\hline Risk Weighted Assets & $\begin{array}{c}0.002^{* * * *} \\
(2.60)\end{array}$ & $\begin{array}{l}-0.000 \\
(-0.33)\end{array}$ & $\begin{array}{c}0.002 * * * \\
(3.14)\end{array}$ & & \\
\hline Loan Commitment & $\begin{array}{c}-0.020 * * * \\
(-10.40)\end{array}$ & $\begin{array}{c}-0.005^{* * * *} \\
(-7.68)\end{array}$ & $\begin{array}{c}-0.013 * * * \\
(-8.87)\end{array}$ & $\begin{array}{c}0.278 * * * \\
(31.09)\end{array}$ & $\begin{array}{c}0.002^{* * *} * \\
(3.31)\end{array}$ \\
\hline Loan Growth & $\begin{array}{c}-0.007 * * * \\
(-8.48)\end{array}$ & $\begin{array}{c}-0.009 * * * \\
(-24.14)\end{array}$ & $\begin{array}{c}-0.006 * * * \\
(-11.34)\end{array}$ & $\begin{array}{c}0.131 * * * \\
(29.84)\end{array}$ & \\
\hline Loan Loss Provision & & & & & $\begin{array}{c}0.015^{* * *} * \\
(5.51)\end{array}$ \\
\hline Liquid Assets & & & & & $\begin{array}{c}-0.006 * * * \\
(-22.03)\end{array}$ \\
\hline Interest Rate Risk & & & & & $\begin{array}{c}-0.008 * * * \\
(-6.66)\end{array}$ \\
\hline Core Deposit & & & & & $\begin{array}{c}0.001 * * * \\
(5.20)\end{array}$ \\
\hline Wage & & & & & $\begin{array}{c}0.002 * * * \\
(7.51)\end{array}$ \\
\hline Size & $\begin{array}{c}0.258 * * * \\
(11.78)\end{array}$ & $\begin{array}{c}0.036^{* * * *} \\
(4.83)\end{array}$ & $\begin{array}{c}0.115^{* * * *} \\
\quad(6.95)\end{array}$ & $\begin{array}{c}-1.268 * * * \\
(-11.62)\end{array}$ & $\begin{array}{c}-0.149 * * * \\
(-14.08)\end{array}$ \\
\hline $\log ($ Age $)$ & $\begin{array}{c}0.286^{* * * *} \\
(7.19)\end{array}$ & $\begin{array}{c}0.060 * * * \\
(4.67)\end{array}$ & $\begin{array}{c}0.107 * * * \\
(3.88)\end{array}$ & $\begin{array}{c}1.688 * * * \\
(10.59)\end{array}$ & $\begin{array}{l}0.019 \\
(1.47)\end{array}$ \\
\hline
\end{tabular}




\begin{tabular}{|c|c|c|c|c|c|}
\hline HHI & $\begin{array}{l}0.019 \\
(0.36)\end{array}$ & $\begin{array}{l}0.012 \\
(0.61)\end{array}$ & $\begin{array}{l}-0.051 \\
(-1.13)\end{array}$ & $\begin{array}{l}-0.010 \\
(-0.05)\end{array}$ & $\begin{array}{c}0.042 * \\
(1.87)\end{array}$ \\
\hline Home Price Growth & $\begin{array}{c}-0.024 * * * \\
(-10.02)\end{array}$ & $\begin{array}{c}-0.003 * * * \\
(-3.58)\end{array}$ & $\begin{array}{c}-0.007 * * * \\
(-3.73)\end{array}$ & $\begin{array}{c}-0.070 * * * \\
(-8.85)\end{array}$ & $\begin{array}{c}0.009 * * * \\
(12.12)\end{array}$ \\
\hline Income Growth & $\begin{array}{c}-0.028 * * * \\
(-12.88)\end{array}$ & $\begin{array}{c}-0.010 * * * \\
(-14.92)\end{array}$ & $\begin{array}{c}-0.029 * * * \\
(-15.27)\end{array}$ & $\begin{array}{l}0.002 \\
(0.24)\end{array}$ & $\begin{array}{c}-0.002^{*} \\
(-1.73)\end{array}$ \\
\hline Acute & $\begin{array}{c}0.102 * * * \\
(11.67)\end{array}$ & $\begin{array}{l}-0.001 \\
(-0.30)\end{array}$ & $\begin{array}{c}0.034 * * * \\
(5.58)\end{array}$ & $\begin{array}{c}0.231 * * * \\
(6.60)\end{array}$ & $\begin{array}{c}-0.039 * * * \\
(-9.71)\end{array}$ \\
\hline Post & $\begin{array}{c}0.092 * * * \\
(7.89)\end{array}$ & $\begin{array}{c}0.059 * * * \\
(15.04)\end{array}$ & $\begin{array}{c}0.158 * * * \\
(18.37)\end{array}$ & $\begin{array}{c}-0.212 * * * \\
(-4.91)\end{array}$ & $\begin{array}{c}0.052 * * * \\
(9.47)\end{array}$ \\
\hline Constant & $\begin{array}{c}0.056^{* * * *} \\
(9.36)\end{array}$ & $\begin{array}{c}0.006^{* * * *} \\
(3.13)\end{array}$ & $\begin{array}{c}-0.008 * \\
(-1.92)\end{array}$ & $\begin{array}{l}-0.033 \\
(-1.49)\end{array}$ & $\begin{array}{c}-0.018 * * * \\
(-7.56)\end{array}$ \\
\hline Observations & 108,630 & 108,630 & 108,632 & 108,644 & 108,407 \\
\hline R-squared & 0.836 & 0.786 & 0.591 & 0.723 & 0.738 \\
\hline Number of Banks & 4,371 & 4,371 & 4,371 & 4,371 & 4,362 \\
\hline
\end{tabular}

See Table A1 for variable definitions. Standard errors are adjusted for clusters in banks. ***, ** and * indicate significance at $1 \%, 5 \%$ and $10 \%$ respectively. 


\section{Table V. Further Issues - Granger Causality Test}

This table reports estimations of Credit Risk and Fiduciary models (Equations (6) \& (7)) using quarterly data of 4,261 NonMicro Commercial Banks during 2003-2010 timespan. Non-Micro Commercial Banks are defined as commercial banks with total assets above \$100 million. Columns (1) and (2) illustrate our Credit Risk analysis and columns (3) and (4) display the estimation of the Fiduciary model.

In the first column, we use Non-performing Loans as our primary proxy for Credit Risk and regress it on its lagged values (three lags) and three lags of Fiduciary, Risk Weighted Assets, Inefficiency and Capital, while controlling for HHI, Home Price Growth and Income Growth and year dummies. In column (2), we add the fourth lagged value to our analysis. Column (3) illustrates our estimation of the Fiduciary model (Equation (7)), where we regress Fiduciary on its lagged value (three lags) and three lags of Credit Risk, three lags of Fiduciary, Risk Weighted Assets, Inefficiency and Capital, while controlling for HHI, Home Price Growth and Income Growth and year dummies. In column (4), we add the fourth lagged value to our analysis. We estimate our models using fixed effect technique.

\begin{tabular}{|c|c|c|c|c|}
\hline & Credit Risk & Credit Risk & Fiduciary & Fiduciary \\
\hline Variables & (1) & (2) & (3) & (4) \\
\hline L. Credit Risk & $\begin{array}{c}0.883 * * * \\
(102.90)\end{array}$ & $\begin{array}{c}0.881 * * * \\
(100.29)\end{array}$ & $\begin{array}{l}0.003 * \\
(1.89)\end{array}$ & $\begin{array}{c}0.003 * \\
(1.74)\end{array}$ \\
\hline L2. Credit Risk & $\begin{array}{l}0.002 \\
(0.18)\end{array}$ & $\begin{array}{l}-0.001 \\
(-0.06)\end{array}$ & $\begin{array}{c}0.008 * * * \\
(4.52)\end{array}$ & $\begin{array}{c}0.009 * * * * \\
(4.58)\end{array}$ \\
\hline L3. Credit Risk & $\begin{array}{c}0.026 * * * \\
(2.70)\end{array}$ & $\begin{array}{l}0.013 \\
(1.16)\end{array}$ & $\begin{array}{l}-0.002 \\
(-1.23)\end{array}$ & $\begin{array}{c}-0.006 * * \\
(-2.26)\end{array}$ \\
\hline L4. Credit Risk & & $\begin{array}{c}0.021 * * \\
(2.28)\end{array}$ & & $\begin{array}{c}0.005 * * * \\
(2.68)\end{array}$ \\
\hline Credit Risk (Total) & - & - & $\begin{array}{c}0.009 * * * \\
(21.55)\end{array}$ & $\begin{array}{c}0.011 * * * * \\
(25.49)\end{array}$ \\
\hline L. Fiduciary & $\begin{array}{l}-0.000 \\
(-0.04)\end{array}$ & $\begin{array}{l}0.001 \\
(0.20)\end{array}$ & $\begin{array}{c}0.683 * * * \\
(22.65)\end{array}$ & $\begin{array}{c}0.666^{* * * *} \\
(20.95)\end{array}$ \\
\hline L2. Fiduciary & $\begin{array}{l}-0.001 \\
(-0.20)\end{array}$ & $\begin{array}{l}-0.002 \\
(-0.30)\end{array}$ & $\begin{array}{c}0.072 * * * \\
(3.15)\end{array}$ & $\begin{array}{c}0.061 * * * * \\
(2.85)\end{array}$ \\
\hline L3. Fiduciary & $\begin{array}{c}-0.009 * \\
(-1.89)\end{array}$ & $\begin{array}{l}-0.004 \\
(-0.67)\end{array}$ & $\begin{array}{c}0.043 * * * \\
(2.78)\end{array}$ & $\begin{array}{l}-0.011 \\
(-0.73)\end{array}$ \\
\hline L4. Fiduciary & & $\begin{array}{l}-0.007 \\
(-0.94)\end{array}$ & & $\begin{array}{c}0.083^{* * *} * \\
(3.60)\end{array}$ \\
\hline Fiduciary (Total) & $\begin{array}{c}-0.010 * * \\
(4.24)\end{array}$ & $\begin{array}{c}-0.012 * * \\
(5.52)\end{array}$ & - & - \\
\hline L. Risk Weighted Assets & $\begin{array}{c}-0.005 * * * \\
(-3.84)\end{array}$ & $\begin{array}{c}-0.005^{* * *} \\
(-3.91)\end{array}$ & $\begin{array}{l}0.001 \\
(1.37)\end{array}$ & $\begin{array}{l}0.001 \\
(1.42)\end{array}$ \\
\hline L2. Risk Weighted Assets & $\begin{array}{l}0.001 \\
(0.53)\end{array}$ & $\begin{array}{l}0.001 \\
(0.34)\end{array}$ & $\begin{array}{l}-0.000 \\
(-0.65)\end{array}$ & $\begin{array}{l}-0.000 \\
(-0.47)\end{array}$ \\
\hline L3. Risk Weighted Assets & $\begin{array}{c}0.005^{* * * *} \\
(4.50)\end{array}$ & $\begin{array}{c}0.003^{*} \\
(1.88)\end{array}$ & $\begin{array}{l}-0.001 \\
(-1.52)\end{array}$ & $\begin{array}{l}-0.000 \\
(-0.04)\end{array}$ \\
\hline L4. Risk Weighted Assets & & $\begin{array}{c}0.004 * * * \\
(3.62)\end{array}$ & & $\begin{array}{c}-0.001 * \\
(-1.90)\end{array}$ \\
\hline Risk Weighted Assets (Total) & $\begin{array}{l}0.001 \\
(2.45)\end{array}$ & $\begin{array}{c}\mathbf{0 . 0 0 3} * * \\
(5.13)\end{array}$ & $\begin{array}{c}-\mathbf{- 0 . 0 0 0} \\
(0.48)\end{array}$ & $\begin{array}{l}-\mathbf{0 . 0 0 0} \\
(1.05)\end{array}$ \\
\hline L. Inefficiency & $\begin{array}{c}0.002 * * * \\
(3.90)\end{array}$ & $\begin{array}{c}0.002 * * * \\
(3.76)\end{array}$ & $\begin{array}{l}-0.000 \\
(-1.26)\end{array}$ & $\begin{array}{l}-0.000 \\
(-1.18)\end{array}$ \\
\hline L2. Inefficiency & $\begin{array}{l}-0.000 \\
(-0.37)\end{array}$ & $\begin{array}{l}-0.000 \\
(-0.33)\end{array}$ & $\begin{array}{c}-0.001 * \\
(-1.83)\end{array}$ & $\begin{array}{l}-0.001 \\
(-1.61)\end{array}$ \\
\hline L3. Inefficiency & $\begin{array}{l}0.000 \\
(0.54)\end{array}$ & $\begin{array}{l}0.001 \\
(1.61)\end{array}$ & $\begin{array}{l}0.000 \\
(0.32)\end{array}$ & $\begin{array}{l}0.000 \\
(1.29)\end{array}$ \\
\hline L4. Inefficiency & & $\begin{array}{c}-0.001 * * \\
(-1.99)\end{array}$ & & $\begin{array}{c}-0.001 * * \\
(-2.42)\end{array}$ \\
\hline Inefficiency (Total) & $\begin{array}{c}0.002 * * * \\
(16.42)\end{array}$ & $\begin{array}{c}0.002 * * * \\
(8.86)\end{array}$ & $\begin{array}{c}-0.001 * * * \\
(9.19)\end{array}$ & $\begin{array}{c}-0.002 * * * * \\
(9.30)\end{array}$ \\
\hline L. Capital & $\begin{array}{c}-0.026 * * * \\
(-5.28)\end{array}$ & $\begin{array}{c}-0.028 * * * \\
(-5.62)\end{array}$ & $\begin{array}{l}-0.002 \\
(-0.80)\end{array}$ & $\begin{array}{l}-0.002 \\
(-0.77)\end{array}$ \\
\hline L2. Capital & $\begin{array}{l}0.007 \\
(1.25)\end{array}$ & $\begin{array}{l}0.006 \\
(1.08)\end{array}$ & $\begin{array}{l}0.002 \\
(0.79)\end{array}$ & $\begin{array}{l}0.002 \\
(0.65)\end{array}$ \\
\hline L3. Capital & $\begin{array}{c}0.007 * \\
(1.67)\end{array}$ & $\begin{array}{l}-0.003 \\
(-0.54)\end{array}$ & $\begin{array}{c}-0.003 * \\
(-1.77)\end{array}$ & $\begin{array}{l}-0.002 \\
(-0.75)\end{array}$ \\
\hline L4. Capital & & $\begin{array}{c}0.015 * * * \\
(3.58)\end{array}$ & & $\begin{array}{l}-0.002 \\
(-0.75)\end{array}$ \\
\hline Capital (Total) & $-0.026 * * *$ & $-0.010 * * *$ & $-0.003 * *$ & $-0.004 * *$ \\
\hline
\end{tabular}




\begin{tabular}{lcccc} 
& $\mathbf{( 1 2 . 6 2 )}$ & $\mathbf{( 6 . 7 3 )}$ & $\mathbf{( 5 . 6 1 )}$ & $\mathbf{( 5 . 1 5 )}$ \\
HHI & 0.082 & $0.119^{*}$ & 0.015 & 0.014 \\
Home Price Growth & $(1.35)$ & $(1.88)$ & $(0.61)$ & $(0.52)$ \\
Income Growth & $-0.027 * * *$ & $-0.027 * * *$ & $-0.003^{* *}$ & $-0.003^{* *}$ \\
& $(-9.93)$ & $(-9.81)$ & $(-2.57)$ & $(-2.48)$ \\
Constant & $-0.017 * * *$ & $-0.017 * * *$ & $0.004 * * *$ & $0.004^{* * *}$ \\
& $(-6.86)$ & $(-6.69)$ & $(3.16)$ & $(2.90)$ \\
Observations & $-0.071 * * *$ & $0.357 * * *$ & -0.003 & $-0.030^{* * *}$ \\
R-squared & $(-7.73)$ & $(35.52)$ & $(-0.61)$ & $(-5.18)$ \\
Number of Banks & 99,470 & 95,014 & 99,404 & 94,948 \\
\hline
\end{tabular}

See Table A1 for variable definitions. Standard errors are adjusted for clusters in banks. ***, ** and * indicate significance at $1 \%, 5 \%$ and $10 \%$ respectively. 


\section{Table VI. Franchise Value Model}

This table illustrates the estimation of the Franchise Value model (Equation (5)) using 1,882 quarterly panel data of Non-Micro Commercial Banks during 2003-2010 period. Non-Micro Commercial Banks are defined as commercial banks with total assets above $\$ 100$ million.

We use the ratio of market to book value of capital equity (Market to Book Value) as the primary proxy for Franchise Value. In the first column, we regress Market to Book Value on our variables of interest, i.e. Fiduciary, Life Insurance, Other Insurance, Loan Servicing, Loan Sale and Service Charge which are scaled by total operating income. In column (2) we introduce Core Deposits to our model. We add Credit Risk and Inefficiency to our analysis in columns (3) and (4), respectively. Capital is included in the fifth column. Column (6) displays the result when we control for Market Share. In column (7) we include state-level control variables, i.e. HHI, Home Price Growth and Income Growth. In column (8), we scale non-interest income items by total assets in lieu of total operating income. In columns (9) and (10) we use Tobin's $Q$ as the alternative proxy for Franchise Value and re-estimate our model with the same specifications of columns (7) and (8). Tobin's $Q$ is defined as the market value of capital equity plus book value of total liabilities divided by book value of total assets. We estimate our model using fixed effect technique and following Petersen (2009) and Thompson (2011) we cluster standard errors at both bank and time levels.

\begin{tabular}{|c|c|c|c|c|c|c|c|c|c|c|}
\hline & $\begin{array}{l}\text { Market to Book } \\
\text { Value }\end{array}$ & $\begin{array}{l}\text { Market to Book } \\
\text { Value }\end{array}$ & $\begin{array}{l}\text { Market to Book } \\
\text { Value }\end{array}$ & $\begin{array}{l}\text { Market to Book } \\
\text { Value }\end{array}$ & $\begin{array}{l}\text { Market to Book } \\
\text { Value }\end{array}$ & $\begin{array}{l}\text { Market to Book } \\
\text { Value }\end{array}$ & $\begin{array}{l}\text { Market to Book } \\
\text { Value }\end{array}$ & $\begin{array}{l}\text { Market to Book } \\
\text { Value }\end{array}$ & Tobin's Q & Tobin's Q \\
\hline Variables & (1) & (2) & (3) & (4) & (5) & (6) & (7) & (8) & (9) & (10) \\
\hline Fiduciary & $\begin{array}{l}17.080^{* * * *} \\
(2.75)\end{array}$ & $\begin{array}{c}16.994 * * * \\
(2.91)\end{array}$ & $\begin{array}{l}14.011 * * * \\
(2.93)\end{array}$ & $\begin{array}{c}15.643 * * * \\
(3.06)\end{array}$ & $\begin{array}{c}15.356^{* * * *} \\
(3.09)\end{array}$ & $\begin{array}{c}15.971 * * * * \\
(3.26)\end{array}$ & $\begin{array}{c}15.811 \text { **** } \\
(3.30)\end{array}$ & $\begin{array}{c}396.775 * * * \\
(3.22)\end{array}$ & $\begin{array}{c}1.596 * * * \\
(3.14)\end{array}$ & $\begin{array}{c}37.899 * * * \\
(3.09)\end{array}$ \\
\hline Life Insurance & $\begin{array}{c}-24.074 * * * \\
(-4.71)\end{array}$ & $\begin{array}{c}-22.133 * * * \\
(-4.27)\end{array}$ & $\begin{array}{c}-18.641 \text { *** } \\
(-4.31)\end{array}$ & $\begin{array}{c}-18.017 * * * \\
(-4.17)\end{array}$ & $\begin{array}{c}-18.161 \text { *** } \\
(-4.15)\end{array}$ & $\begin{array}{c}-18.332 * * * \\
(-4.17)\end{array}$ & $\begin{array}{c}-6.747 * \\
(-1.73)\end{array}$ & $\begin{array}{c}-169.125^{*} \\
(-1.72)\end{array}$ & $\begin{array}{l}-0.575 \\
(-1.59)\end{array}$ & $\begin{array}{c}-15.904 * \\
(-1.68)\end{array}$ \\
\hline Other Insurance & $\begin{array}{l}8.629 \\
(1.12)\end{array}$ & $\begin{array}{l}8.577 \\
(1.15)\end{array}$ & $\begin{array}{l}4.062 \\
(0.74)\end{array}$ & $\begin{array}{l}4.599 \\
(0.79)\end{array}$ & $\begin{array}{l}5.029 \\
(0.87)\end{array}$ & $\begin{array}{l}5.229 \\
(0.91)\end{array}$ & $\begin{array}{l}2.389 \\
(0.44)\end{array}$ & $\begin{array}{c}52.688 \\
(0.46)\end{array}$ & $\begin{array}{l}-0.078 \\
(-0.12)\end{array}$ & $\begin{array}{l}1.989 \\
(0.17)\end{array}$ \\
\hline Loan Servicing & $\begin{array}{c}-11.733 * \\
(-1.93)\end{array}$ & $\begin{array}{c}-9.373 * \\
(-1.73)\end{array}$ & $\begin{array}{l}-6.182 \\
(-1.36)\end{array}$ & $\begin{array}{l}-5.299 \\
(-1.18)\end{array}$ & $\begin{array}{l}-5.143 \\
(-1.10)\end{array}$ & $\begin{array}{l}-5.827 \\
(-1.27)\end{array}$ & $\begin{array}{l}-1.308 \\
(-0.30)\end{array}$ & $\begin{array}{c}45.370 \\
(0.35)\end{array}$ & $\begin{array}{l}-0.266 \\
(-0.49)\end{array}$ & $\begin{array}{l}7.169 \\
(0.41)\end{array}$ \\
\hline Loan Sale & $\begin{array}{l}0.004 \\
(0.00)\end{array}$ & $\begin{array}{l}-0.139 \\
(-0.08)\end{array}$ & $\begin{array}{l}0.423 \\
(0.28)\end{array}$ & $\begin{array}{l}0.376 \\
(0.26)\end{array}$ & $\begin{array}{l}0.369 \\
(0.25)\end{array}$ & $\begin{array}{l}0.375 \\
(0.26)\end{array}$ & $\begin{array}{l}0.442 \\
(0.29)\end{array}$ & $\begin{array}{l}13.253 \\
(0.55)\end{array}$ & $\begin{array}{l}0.049 \\
(0.29)\end{array}$ & $\begin{array}{l}2.549 \\
(0.93)\end{array}$ \\
\hline Service Charge & $\begin{array}{c}-6.551 * * * \\
(-3.46)\end{array}$ & $\begin{array}{c}-6.722 * * * \\
(-3.55)\end{array}$ & $\begin{array}{c}-5.054 * * * \\
(-3.44)\end{array}$ & $\begin{array}{c}-3.933 * * * \\
(-2.70)\end{array}$ & $\begin{array}{c}-3.843^{* * * *} \\
(-2.62)\end{array}$ & $\begin{array}{c}-3.941 * * * \\
(-2.67)\end{array}$ & $\begin{array}{l}-2.589 \\
(-1.53)\end{array}$ & $\begin{array}{c}-51.530 \\
(-1.34)\end{array}$ & $\begin{array}{c}-0.355^{* *} \\
(-2.24)\end{array}$ & $\begin{array}{l}-5.920 \\
(-1.62)\end{array}$ \\
\hline Core Deposit & & $\begin{array}{c}0.757^{*} \\
(1.85)\end{array}$ & $\begin{array}{c}0.889 * * * \\
(2.72)\end{array}$ & $\begin{array}{c}0.981 * * * \\
(2.98)\end{array}$ & $\begin{array}{c}0.980 * * * \\
(2.94)\end{array}$ & $\begin{array}{c}0.950 * * * \\
(2.85)\end{array}$ & $\begin{array}{c}0.681^{* *} \\
(2.10)\end{array}$ & $\begin{array}{c}0.722 * * \\
(2.25)\end{array}$ & $\begin{array}{l}0.056 \\
(1.50)\end{array}$ & $\begin{array}{l}0.058 \\
(1.57)\end{array}$ \\
\hline Credit Risk & & & $\begin{array}{c}-18.832 * * * \\
(-7.65)\end{array}$ & $\begin{array}{c}-17.545^{* * * *} \\
(-7.11)\end{array}$ & $\begin{array}{c}-16.811^{* * *} \\
(-6.24)\end{array}$ & $\begin{array}{c}-16.981 \text { *** } \\
(-6.22)\end{array}$ & $\begin{array}{c}-17.639 * * * \\
(-4.32)\end{array}$ & $\begin{array}{c}-17.626 * * * \\
(-4.33)\end{array}$ & $\begin{array}{c}-1.496^{* * *} \\
(-3.57)\end{array}$ & $\begin{array}{c}-1.495 * * * \\
(-3.59)\end{array}$ \\
\hline Inefficiency & & & & $\begin{array}{c}-0.365^{* * *} \\
(-2.84)\end{array}$ & $\begin{array}{c}-0.341 * * \\
(-2.50)\end{array}$ & $\begin{array}{c}-0.344 * * \\
(-2.52)\end{array}$ & $\begin{array}{l}-0.197 \\
(-1.44)\end{array}$ & $\begin{array}{c}-0.260 * * \\
(-1.98)\end{array}$ & $\begin{array}{l}-0.017 \\
(-1.02)\end{array}$ & $\begin{array}{l}-0.026 \\
(-1.53)\end{array}$ \\
\hline Capital & & & & & $\begin{array}{l}1.213 \\
(1.02)\end{array}$ & $\begin{array}{l}1.029 \\
(0.86)\end{array}$ & $\begin{array}{l}-0.422 \\
(-0.27)\end{array}$ & $\begin{array}{l}-0.306 \\
(-0.20)\end{array}$ & $\begin{array}{l}0.221 \\
(1.18)\end{array}$ & $\begin{array}{l}0.226 \\
(1.21)\end{array}$ \\
\hline Market Share & & & & & & $\begin{array}{l}-5.982 \\
(-0.99)\end{array}$ & $\begin{array}{c}-9.079^{*} \\
(-1.70)\end{array}$ & $\begin{array}{c}-8.877^{*} \\
(-1.66)\end{array}$ & $\begin{array}{l}-0.604 \\
(-1.16)\end{array}$ & $\begin{array}{l}-0.573 \\
(-1.10)\end{array}$ \\
\hline HHI & & & & & & & $\begin{array}{c}-97.505 * * * \\
(-2.75)\end{array}$ & $\begin{array}{c}-95.357 * * * \\
(-2.67)\end{array}$ & $\begin{array}{c}-8.049 * * \\
(-2.39)\end{array}$ & $\begin{array}{c}-7.632 * * \\
(-2.30)\end{array}$ \\
\hline Home Price Growth & & & & & & & $\begin{array}{c}5.056^{* * * *} \\
(3.70)\end{array}$ & $\begin{array}{c}5.041^{* * * *} \\
(3.68)\end{array}$ & $\begin{array}{c}0.595^{* * * *} \\
(4.15)\end{array}$ & $\begin{array}{c}0.594 * * * * \\
(4.18)\end{array}$ \\
\hline Income Growth & & & & & & & $\begin{array}{c}4.815^{* * * *} \\
(3.21)\end{array}$ & $\begin{array}{c}4.950 * * * \\
(3.28)\end{array}$ & $\begin{array}{c}0.535^{* * * *} \\
(3.60)\end{array}$ & $\begin{array}{c}0.556 * * * \\
(3.70)\end{array}$ \\
\hline
\end{tabular}




\begin{tabular}{|c|c|c|c|c|c|c|c|c|c|c|}
\hline Constant & $\begin{array}{c}75.834 \\
(0.82)\end{array}$ & $\begin{array}{c}-44.622 \\
(-0.50)\end{array}$ & $\begin{array}{l}61.040 \\
(0.86)\end{array}$ & $\begin{array}{l}56.492 \\
(0.74)\end{array}$ & $\begin{array}{c}51.817 \\
(0.69)\end{array}$ & $\begin{array}{c}48.943 \\
(0.65)\end{array}$ & $\begin{array}{c}-17.946 \\
(-0.26)\end{array}$ & $\begin{array}{c}20.019 \\
(0.97)\end{array}$ & $\begin{array}{l}-5.780 \\
(-0.71)\end{array}$ & $\begin{array}{l}1.996 \\
(1.04)\end{array}$ \\
\hline Observations & 2,834 & 2,834 & 2,834 & 2,834 & 2,834 & 2,834 & 1,882 & 1,882 & 1,882 & 1,882 \\
\hline R-squared & 0.557 & 0.565 & 0.628 & 0.634 & 0.635 & 0.637 & 0.710 & 0.710 & 0.710 & 0.709 \\
\hline
\end{tabular}

See Table A1 for variable definitions. Standard errors are adjusted for clusters in banks. ***,** and * indicate significance at $1 \%, 5 \%$ and $10 \%$ respectively. 


\section{Table VII. Cost Complementarities Analysis}

This table reports Cost Complementarities analysis (Equation (3)), between the non-interest income activities and loans (secured and unsecured loans (Y1 \& Y2)) for Micro and Non-Micro Commercial Banks. Micro Commercial Banks are defined as banks with less than $\$ 100$ million in total assets. Non-Micro Commercial Banks are commercial banks with total assets above $\$ 100$ million.

The first three columns present the analysis for the Non-Micro Commercial Banks and columns (4) to (6) exhibit the results for Micro Commercial Banks. Columns (1) and (4) display the necessary condition for the existence of cost complementarities or diseconomy of joint production between the non-interest income activities and secured or unsecured loans. In columns (2) and (5) the measure of cost complementarities (or diseconomy of joint production) are illustrated. See Table A1 for variable definitions. In the first four rows we use stochastic frontier analysis to estimate our total cost function, whereas rows (5) to (8) exhibit the results when we employ the fixed effect technique for our estimations. We adopt two cost functions: intermediation approach (Berger and Mester, 1997 among others) and production approach (Berger and DeYoung, 1997 among others).

\begin{tabular}{|c|c|c|c|c|c|c|c|c|c|}
\hline & & & & \multicolumn{3}{|c|}{ Non-Micro Commercial Banks } & \multicolumn{3}{|c|}{ Micro Commercial Banks } \\
\hline & & & & NC_PCC(Yi, Y5) & $\mathrm{PCC}(\mathrm{Yi}, \mathrm{Y5})$ & $\begin{array}{c}\text { Marginal } \\
\text { Cost }\end{array}$ & NC_PCC(Yi, Y5) & $\mathrm{PCC}(\mathrm{Yi}, \mathrm{Y5})$ & $\begin{array}{l}\text { Marginal } \\
\text { Cost }\end{array}$ \\
\hline & & & & (1) & (2) & (3) & (4) & (5) & (6) \\
\hline \multirow{4}{*}{ 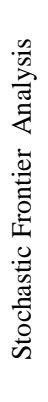 } & .: & (1) & $\begin{array}{l}\text { Secured Loans } \\
\text { (Y1) }\end{array}$ & 0.000382 & 0.000000 & 0.0969 & 0.008652 & 0.000063 & 0.0533 \\
\hline & 产 & (2) & $\begin{array}{l}\text { Unsecured Loans } \\
\text { (Y2) }\end{array}$ & -0.000586 & 0.000000 & 0.0220 & 0.000132 & 0.000048 & 0.0515 \\
\hline & 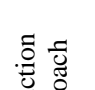 & (3) & $\begin{array}{l}\text { Secured Loans } \\
\text { (Y1) }\end{array}$ & -0.000870 & 0.000000 & 0.1088 & 0.008577 & 0.000063 & 0.0851 \\
\hline & D串 & (4) & $\begin{array}{l}\text { Unsecured Loans } \\
\text { (Y2) }\end{array}$ & -0.000533 & 0.000000 & 0.0250 & 0.000117 & 0.000034 & 0.0573 \\
\hline \multirow{4}{*}{ 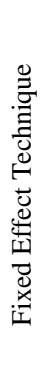 } & . : & (5) & $\begin{array}{l}\text { Secured Loans } \\
\text { (Y1) }\end{array}$ & 0.000818 & 0.000000 & 0.0953 & 0.009879 & 0.000087 & 0.0614 \\
\hline & 绨 & (6) & $\begin{array}{l}\text { Unsecured Loans } \\
\text { (Y2) }\end{array}$ & -0.000625 & 0.000000 & 0.0176 & 0.000331 & 0.000071 & 0.0589 \\
\hline & 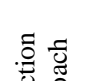 & (7) & $\begin{array}{l}\text { Secured Loans } \\
\text { (Y1) }\end{array}$ & -0.000220 & 0.000000 & 0.1080 & 0.009922 & 0.000093 & 0.0880 \\
\hline & 定 & (8) & $\begin{array}{l}\text { Unsecured Loans } \\
\text { (Y2) }\end{array}$ & -0.000576 & 0.000000 & 0.0216 & 0.000302 & 0.000066 & 0.0728 \\
\hline
\end{tabular}

